\title{
Drug Toxicity Evaluation Based on Organ-on-a-Chip Technology: A Review
}

\author{
Ye Cong ${ }^{1}$, Xiahe Han ${ }^{2}$, Youping Wang ${ }^{2}$, Zongzheng Chen ${ }^{3}{ }^{\oplus}$, Yao Lu ${ }^{4}{ }^{\oplus}$, Tingjiao Liu ${ }^{5}$, \\ Zhengzhi $\mathrm{Wu}^{3}{ }^{3}$, $\mathrm{u}$ Jin ${ }^{3}$, Yong Luo ${ }^{1, *}$ and Xiuli Zhang ${ }^{2, *}$ \\ 1 State Key Laboratory of Fine Chemicals, Department of Chemical Engineering, Dalian University of \\ Technology, Dalian 116023, China; cycie196@163.com \\ 2 College of Pharmaceutical Science, Soochow University, Suzhou 215123, China; \\ 20194226017@stu.suda.edu.cn (X.H.); 20194226030@stu.suda.edu.cn (Y.W.) \\ 3 Health Science Center, Shenzhen University, Shenzhen 518060, China; chenmond@foxmail.com (Z.C.); \\ szwzz001@email.szu.edu.cn (Z.W.); nnjinyu@sina.com (Y.J.) \\ 4 Biotechnologhy Division, Dalian Institute of Chemical Physics, Chinese Academy of Sciences, Dalian 116023, \\ China; luyao@dicp.ac.cn \\ 5 College of Stomatology, Dalian Medical University, Dalian 116011, China; tingjiao@dmu.edu.cn \\ * Correspondence: yluo@dlut.edu.cn (Y.L.); zhangxl@suda.edu.cn (X.Z.); Tel.: +86-0411-84986360 (Y.L.)
}

Received: 1 March 2020; Accepted: 25 March 2020; Published: 3 April 2020

\begin{abstract}
Organ-on-a-chip academic research is in its blossom. Drug toxicity evaluation is a promising area in which organ-on-a-chip technology can apply. A unique advantage of organ-on-a-chip is the ability to integrate drug metabolism and drug toxic processes in a single device, which facilitates evaluation of toxicity of drug metabolites. Human organ-on-a-chip has been fabricated and used to assess drug toxicity with data correlation with the clinical trial. In this review, we introduced the microfluidic chip models of liver, kidney, heart, nerve, and other organs and multiple organs, highlighting the application of these models in drug toxicity detection. Some biomarkers of toxic injury that have been used in organ chip platforms or have potential for use on organ chip platforms are summarized. Finally, we discussed the goals and future directions for drug toxicity evaluation based on organ-on-a-chip technology.
\end{abstract}

Keywords: organ-on-a-chip; drug toxicity; drug metabolism

\section{Introduction}

Animal models have been widely used in the field of pre-clinical testing and toxicity testing of drugs [1]. However, the results obtained by animal models are often different from those of humans, which has led to the withdrawal of many drugs from the clinical stage due to adverse effects. Traditional in vitro 2D cultures can replace animal models to a certain extent, but cannot replicate the physiological environment of cells in vivo. Moreover, the lack of cell-to-cell and cell-to-matrix interactions in 2D cultures often leads to the loss of cell function. Therefore, building more bionic and stable in vitro research models has gradually become a hot topic.

Microfluidic chip development is a branch of technology that studies micro/sub-micron scale fluid control. Initially, microfluidic chips were used to replace the traditional analytical method of laboratory analysis by constructing a " $\mu$-TAS" or "lab-on-a-chip" model with microchromatography and capillary electrophoresis [2]. With the widespread application of microfluidic chip technology, people began to apply it to the fields of cell biology and cell analysis, and technically realized cell culture on-chip, simulation and construction of in vivo microenvironment on-chip, single-cell analysis chips, and further "organ-on-a-chip" models. [3,4]. 
Organ-on-a-chip is a specialized subtype of the microfluidic chip which mimics functional units of human organs in vitro. It includes the cell microenvironment, and the cell-to-cell co-culture and interactions. The organ-on-a-chip model can more accurately adjust the environmental conditions related to its growth and function according to the type of cells it cultures. Flow culture can control the supply of nutrients and remove accumulated cellular waste or secondary metabolites from the culture medium. Also, it can regulate the oxygenation level, shear stress guarantees the barrier integrity of the cell layer, and it can control cell migration in vitro [5]. On the organ-on-a-chip models, one can use cells to regenerate many functions that are difficult to achieve in traditional in vitro models. For example, reconstruction of tissue barrier function, cultivation of parenchymal tissue, and integration of multiple organ functions [6]. In the last decade, academic research on organ-on-a-chip systems has boomed. Researchers have also achieved further development of organ-on-a-chip technology.

Cell-based 3D culture models spheroids and organoids are widely used in in vitro tissue and organ reconstruction. Spheroids can be used to reproduce tissues or organs such as tumors, the liver, and nerves in vitro from primary cells or cell lines [7-9]. Organoids are a new three-dimensional culture model enabling miniaturized organs produced by stem cells in vitro. Through appropriate growth factor treatment, stem cell differentiation and self-organization into organ-specific cell types and tissues occurs, recreating the structure and function of organs in vitro [10]. Combining the 3D culture of organs or tissues with microfluidic chip technology can provide a more suitable differentiation and culture environment and improve tissue or organ function and sensitivity to stimulation. Therefore, people began to use spheroid/organoid-on-a-chip for physiological in vitro research. Some of the latest applications have been described by Dongeun Huh [11]. The article pointed out that this technology was expected to be the most advantageous weapon to solve the key issues of new drug development. Furthermore, compared with the traditional organoid technology, the organ chip can more accurately control the local environment and simulate human organ function in vitro, which is more advantageous in applications.

Drug toxicity is one of the major reasons for post-market drug withdrawal; therefore it is crucial to perform preclinical toxicity testing on candidate drugs. Owing to the existence of species differences, the results obtained from animal models cannot be fully adapted to humans [12]. In order to improve the accuracy of drug preclinical test results, many in vitro models have been constructed for toxicity screening, and organ-on-a-chip is a superior one.

To simulate the toxic effects of drug candidates on different cells, tissues, or organs of the human body, scientists have constructed many organ-on-a-chip models that simulate single or multiple organs, e.g., the liver [13]-, kidney [14]-, heart [15]-, nerves [16]-, and multi-organs-on-chips [17]. These models have been proven to have the potential to develop into new platforms for drug toxicity detection [18]. In this review, we will summarize the latest drug toxicity assessments based on organ chips.

\section{Biomarkers for Drug Toxicity Testing}

The selection of appropriate biomarkers is critical for drug toxicity testing, and the high expression of biomarkers in in vitro models will lower the detection limit. This section summarizes the toxic biomarkers used in in vitro models (Table 1).

Table 1. Some common biomarkers for drug toxicity evaluation.

\begin{tabular}{ccccc}
\hline Toxicity & Biomarker & Reference & Specification & $\begin{array}{c}\text { Whether Utilized } \\
\text { with Organ Chips }\end{array}$ \\
\hline \multirow{2}{*}{ Hepatotoxicity } & $\begin{array}{c}\text { ALT (alanine } \\
\text { aminotransferase) } \\
\text { AST (aspartate } \\
\text { aminotransferase) }\end{array}$ & {$[19]$} & $\begin{array}{c}\text { Diagnostic marker of liver } \\
\text { damage }\end{array}$ & $\sqrt{ }$ \\
\cline { 2 - 5 } & ALP (alkalinephosphatase) & {$[19]$} & $\begin{array}{c}\text { Diagnostic marker of } \\
\text { cholestatic injury }\end{array}$ & $\sqrt{ }$ \\
\cline { 2 - 5 } & $\begin{array}{c}\text { GLDH (glutamate } \\
\text { dehydrogenase) }\end{array}$ & {$[20]$} & Early detection biomarker & $\times$ \\
\hline
\end{tabular}


Table 1. Cont.

\begin{tabular}{|c|c|c|c|c|}
\hline Toxicity & Biomarker & Reference & Specification & $\begin{array}{l}\text { Whether Utilized } \\
\text { with Organ Chips }\end{array}$ \\
\hline \multirow{8}{*}{ Hepatotoxicity } & $\begin{array}{l}\text { HMGB-1 (high-mobility } \\
\text { group box 1) }\end{array}$ & [21] & Early detection biomarker & $\times$ \\
\hline & K18 (keratin-18) & [22] & Early detection biomarker & $\sqrt{ }$ \\
\hline & $\begin{array}{c}\text { OCT (ornithine } \\
\text { carbamoyltransferase) }\end{array}$ & [23] & Early detection biomarker & $x$ \\
\hline & $\begin{array}{l}\text { GST- } \alpha \text { (glutathione } \\
\text { S-transferase } \alpha \text { ) }\end{array}$ & [24] & Early detection biomarker & $\sqrt{ }$ \\
\hline & CYP (cytochrome P450) & [25] & Metabolic ability biomarke & $\sqrt{ }$ \\
\hline & miRNA-122, miRNA-192 & [26] & Genomic markers & $\sqrt{ }$ \\
\hline & CDH-5 (cadherin-5) & [27] & Proteomics biomarker & $\sqrt{ }$ \\
\hline & $\begin{array}{l}\text { FABP1 (fatty acid binding } \\
\text { protein } 1 \text { ) }\end{array}$ & [27] & Proteomics biomarker & $\times$ \\
\hline \multirow{13}{*}{ nephrotoxicity } & $\begin{array}{l}\text { GFR (glomerular filtration } \\
\text { rate) }\end{array}$ & [28] & $\begin{array}{l}\text { Diagnostic marker of renal } \\
\text { function }\end{array}$ & $\sqrt{ }$ \\
\hline & SCr levels and urine output & [29] & $\begin{array}{l}\text { Diagnostic marker of AKI } \\
\text { (acute kidney injury) }\end{array}$ & $\sqrt{ }$ \\
\hline & $\begin{array}{l}\text { KIM-1 (kidney injury } \\
\text { molecule-1) }\end{array}$ & [30] & Early detection biomarker & $\sqrt{ }$ \\
\hline & $\begin{array}{c}\text { NAG } \\
\text { (N-acetyl- } \beta \text {-glucosaminidase) }\end{array}$ & [30] & Early detection biomarker & $\sqrt{ }$ \\
\hline & $\begin{array}{l}\text { NGAL (neutrophil } \\
\text { gelatinase-associated } \\
\text { lipocalin) }\end{array}$ & [31] & Early detection biomarker & $\sqrt{ }$ \\
\hline & $\begin{array}{l}\text { L-FABP (liver type fatty acid } \\
\text { binding protein) }\end{array}$ & [32] & Early detection biomarker & $x$ \\
\hline & $\begin{array}{c}\text { MCP-1 (monocyte } \\
\text { chemotactic peptide-1) }\end{array}$ & [33] & Early detection biomarker & $x$ \\
\hline & CYs C (cystatin C) & [34] & Early detection biomarker & $\sqrt{ }$ \\
\hline & OPN (osteopontin) & [35] & Early detection biomarker & $x$ \\
\hline & CLU (clusterin) & [36] & Early detection biomarker & $x$ \\
\hline & TFF3 (trefoil factor 3) & [37] & Early detection biomarker & $x$ \\
\hline & $\begin{array}{l}\text { TEER (transendothelial } \\
\text { resistance) }\end{array}$ & [38] & $\begin{array}{l}\text { Biomarker of barrier } \\
\text { functions }\end{array}$ & $\sqrt{ }$ \\
\hline & miRNAs & [39] & Genomic markers & $\sqrt{ }$ \\
\hline \multirow{7}{*}{ cardiotoxicity } & $\begin{array}{l}\text { LVDP (left ventricular } \\
\text { formation pressure) } \\
\text { LVSP (left ventricular } \\
\text { systolic pressure) }\end{array}$ & [40] & $\begin{array}{l}\text { Diagnostic marker of } \\
\text { myocardial injury }\end{array}$ & $\sqrt{ }$ \\
\hline & $\begin{array}{l}\text { TnI (troponin I) } \\
\text { TnT (troponin T) }\end{array}$ & [41] & Early detection biomarker & $x$ \\
\hline & $\begin{array}{c}\text { BNP (brain natriuretic } \\
\text { peptide) } \\
\text { NT-proBNP }\end{array}$ & [42] & Early detection biomarker & $x$ \\
\hline & MPO (myeloperoxidase) & [43] & $\begin{array}{l}\text { Biomarker of oxidative } \\
\text { stress }\end{array}$ & $\times$ \\
\hline & $\begin{array}{l}\text { miR-146a, miR-1, miR-133, } \\
\text { miR-208, miR-499 }\end{array}$ & [44] & Genomic markers & $\sqrt{ }$ \\
\hline & $\begin{array}{l}\text { beating frequency, systolic } \\
\text { stress, field potential }\end{array}$ & {$[45,46]$} & Mechanical markers & $\sqrt{ }$ \\
\hline & TEER & [47] & $\begin{array}{l}\text { Biomarker of barrier } \\
\text { functions }\end{array}$ & $\sqrt{ }$ \\
\hline
\end{tabular}


Table 1. Cont.

\begin{tabular}{|c|c|c|c|c|}
\hline Toxicity & Biomarker & Reference & Specification & $\begin{array}{l}\text { Whether Utilized } \\
\text { with Organ Chips }\end{array}$ \\
\hline \multirow{6}{*}{ neurotoxicity } & $\begin{array}{c}\text { plasma P-Tau } \\
\text { (phosphorylated-Tau) } \\
\text { T-Tau (total Tau) } \\
\end{array}$ & [48] & $\begin{array}{l}\text { Diagnostic marker of } \\
\text { central nervous system } \\
\text { (CNS) injury }\end{array}$ & $x$ \\
\hline & $\begin{array}{l}\text { NF-H (neurofilaments heavy } \\
\text { subunit) }\end{array}$ & [49] & $\begin{array}{l}\text { Diagnostic marker of } \\
\text { axonal injury }\end{array}$ & $x$ \\
\hline & $\begin{array}{c}\text { miR-425-p, miR-21, miR-93, } \\
\text { miR-191, miR-499,miR-328, } \\
\text { miR-362-3p, miR-451, } \\
\text { miR-486a }\end{array}$ & [50] & Genomic markers & $\sqrt{ }$ \\
\hline & $\begin{array}{l}\text { H-FABP (heart fatty acid } \\
\text { binding protein) }\end{array}$ & [51] & $\begin{array}{c}\text { Diagnostic marker of CNS } \\
\text { injury }\end{array}$ & $x$ \\
\hline & $\begin{array}{l}\text { SP, sCD40L, TIMP-1, MDA, } \\
\text { CK-18 }\end{array}$ & [52] & Early detection biomarkers & $\sqrt{ }$ \\
\hline & MBG (marinobufagenin) & [53] & $\begin{array}{c}\text { Biomarker of } \\
\text { neuro-inflammation }\end{array}$ & $x$ \\
\hline \multirow{8}{*}{ other toxicities } & Ghrelin & [54] & $\begin{array}{c}\text { Biomarker of } \\
\text { stomach/small intestine } \\
\text { injury }\end{array}$ & $x$ \\
\hline & $\begin{array}{l}\text { DAO (diamine oxidase) } \\
\text { Citrulline }\end{array}$ & [54] & $\begin{array}{l}\text { Biomarker of small } \\
\text { intestine injury }\end{array}$ & $x$ \\
\hline & CD64, C-reactive protein & [54] & $\begin{array}{l}\text { Biomarker of small/large } \\
\text { intestine }\end{array}$ & $\sqrt{ }$ \\
\hline & NOS isoenzymes & [55] & Breath biomarkers & $\sqrt{ }$ \\
\hline & HO (heme oxygenase) & [56] & $\begin{array}{l}\text { Biomarker of upper } \\
\text { respiratory tract viral } \\
\text { infections }\end{array}$ & $\sqrt{ }$ \\
\hline & $\begin{array}{l}\text { CYP (cytochrome P450) } \\
\text { H2O2 }\end{array}$ & [57] & $\begin{array}{l}\text { Biomarker of pulmonary } \\
\text { diseases }\end{array}$ & $\sqrt{ }$ \\
\hline & $\begin{array}{l}\text { Breath methylated } \\
\text { hydrocarbons }\end{array}$ & [58] & $\begin{array}{l}\text { Lipid peroxidation } \\
\text { markers }\end{array}$ & $x$ \\
\hline & TEER & [59] & $\begin{array}{l}\text { Biomarker of barrier } \\
\text { functions }\end{array}$ & $\sqrt{ }$ \\
\hline
\end{tabular}

\section{Drug Hepatotoxicity Testing by Liver-on-a-Chip}

\subsection{Overview of Liver and Hepatotoxicity}

The liver is the largest internal organ in the human body. Its main function is metabolism, and it also plays a central role in detoxification, storage of glycogen, and synthesis of secreted proteins in the body. Liver is a major target organ of drug toxicity. Drug-induced liver injury (DILI) can cause drug withdrawal from market and acute and chronic liver disease, and is a major safety issue in drug development. Liver-on-a-chip is a state-of-art technique to detect drug hepatotoxicity.

\subsection{Research Progress of Liver Chips for Drug Toxicity Testing}

Before inception of the liver chip, preclinical determination of drug hepatotoxicity relied on immortalized cell lines and primary isolated hepatocytes (HepG2) [60]. Rapid loss of activity and reduced liver specific functions and gene expression are common shortcomings of these models [61]. Animal experiments have long experimental cycles, are costly, and have ethical and animal welfare problems. Therefore, there is a need to establish a new in vitro platform that can preserve the cell microenvironment in vivo, simulate various functions of liver tissues in the body, and achieve long-term repeated administration. Liver chips meet these requirements. 
Bhise et al. developed a liver chip for long-term culture of human HepG2 cells or C3A cells. HepG2 cells or C3A cells were embedded in photo-crosslinked gelatin methacrylate hydrogel to make spheroids. The spheroids were arranged in a microfluidic chip and liver toxicity was assessed by detecting changes in specific markers. In this platform, the spheroids still retain their activity for 30 days, and have proven their potential for drug toxicity assessment [62]. Zuchowska et al. [63] also used 3D spherical culture of HepG2 cells to detect the hepatotoxicity of the anti-cancer drug 5-fluorouracil (5-FU), and found that as the diameter of the sphere increased, HepG2 cells reduced resistance to 5-FU at two test concentrations.

Besides the spheroidal culture, co-culture techniques also have been widely used in liver chips to establish a microenvironment that is closer to the body and maintains liver cell functions. Especially, co-culture of parenchymal cells and non-parenchymal cells (stellate cells, sinusoidal endothelial cells, Kupffer cells) is important for achieving cell-to-cell contact and transmission of signal molecules, enhancing liver cell functions. Kostadinova et al. [64] established a nylon scaffold that allows three-dimensional culture of HepG2 and non-parenchymal cells including Kupffer cells, stellate cells, sinusoidal endothelial cells, and bile duct endothelial cells, which can maintain the specific functions of the liver long-term, form bile duct-like structures, and respond to inflammatory stimuli. Ma et al. [65] developed a microfluidic device that mimics the hepatic lobular-like structure. The experiments found that co-culture of HepG2 and non-parenchymal cells (HAECs) formed hepatic cord-like structures and hepatic sinusoidal structures. The ability to maintain co-culture of HepG2 and non-parenchymal cells makes this system an alternative for hepatotoxicity testing. This study proved that the combination of three-dimensional culture and co-culture in the liver chip can better mimic the complex human liver system, which not only achieved longer-term culture and maintained good liver function, but also simulated the toxic response of whole liver organ to drug candidates. Jang et al. [66] constructed a human, dog, and rat two-cell and four-cell species-specific liver chip, and used this chip in combination with microscopic observation, fluorescent staining, and biomarker labeling to verify a variety of phenotypes for drug-induced liver injury, correlation between species-specific liver chips and human liver chips, and identification of specific drug-induced liver toxicity damage and mechanisms (Figure 1A).
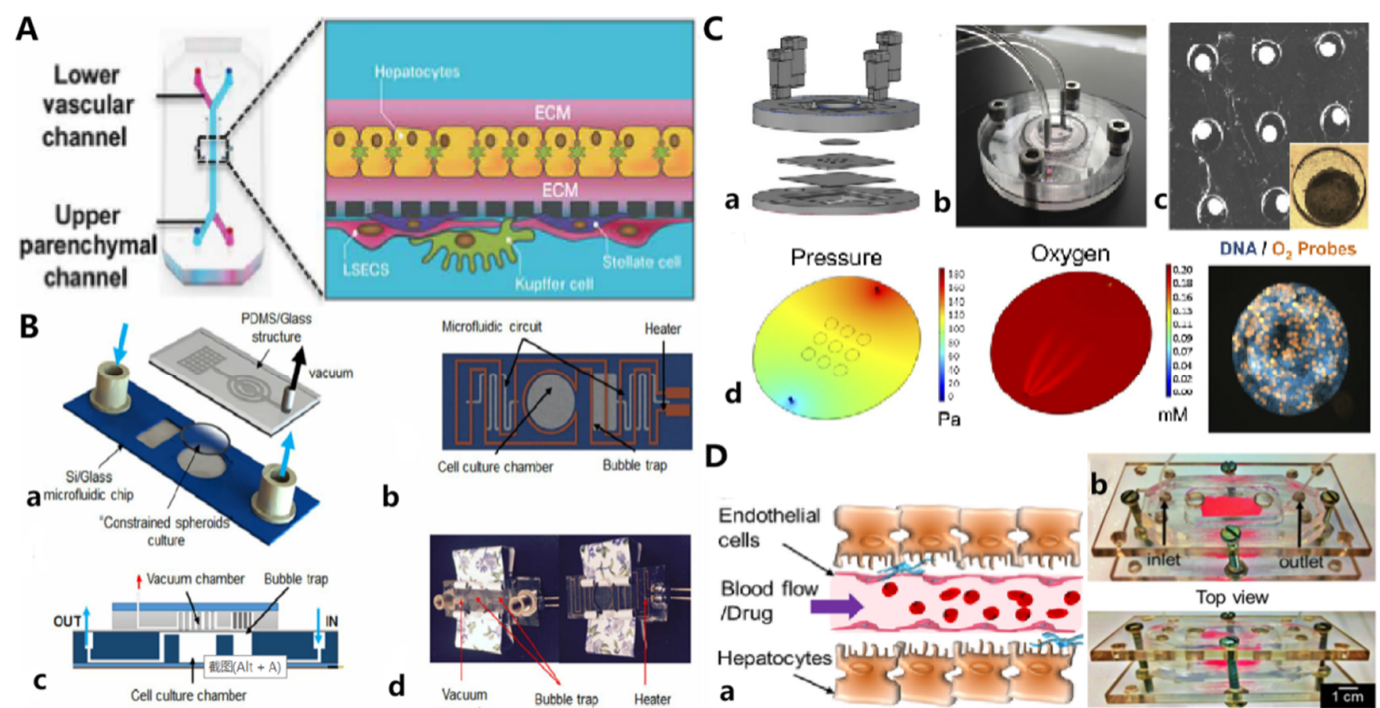

b
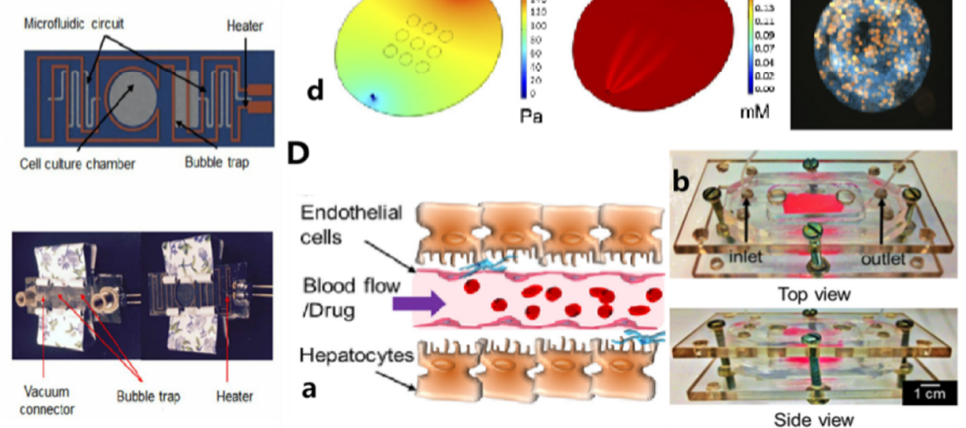

Figure 1. A liver chip system for drug toxicity testing. (A) Specific cell type (human, dog, rat) four-cell culture chip used for drug toxicity test [66]; (B) Perfusion-incubator-liver-chip (PIC) using $\mathrm{CO}_{2}$ gas pressure to drive the perfusion medium, which can be used for chronic toxicity repeated dose drug toxicity tests [67] (C) Liver chip combined with fluorescent probe to track mitochondrial function status in real time to monitor cell viability and metabolic function [68]; (D) Liver chip microdevice with a vascular layer, which is helpful for predicting the mechanism of drug liver toxicity at the microcirculation level [69]. 
When culturing the hepatic cells in liver chips, perfusion culture technology has been widely employed. Deng et al. [70] constructed a hepatic sinusoidal chip device consisting of four transformed cell lines and perfused it with a peristaltic pump. The cell composition, proportion, and spatial arrangement were similar to the physiological characteristics of hepatic sinusoids in the body, enhancing the sensitivity of HepG2 cell toxicity drug testing, and also realizing the study of drug-drug interactions. In addition to peristaltic perfusion, gravity-driven, paper-based siphon and $\mathrm{CO}_{2}$ gas-driven perfusion methods were also effectively applied to liver chips. Yu et al. [67] constructed a perfusion-incubator-liver-chip (PIC) that integrated air bubbles and temperature processing functions. In addition, it drove the flow using $\mathrm{CO}_{2}$ pressure and achieved $\mathrm{pH}$ control, maintaining liver cell viability for 14 days with persistent good function. This chip was used to investigate acute and chronic drug hepatotoxicity of acetaminophen and diclofenac (Figure 1B). Jang et al. [71] added a phase guide to a 3D perfusion chip without using a pump. In recent years, innovations in perfusion culture technology have not only enabled better simulation of the in vivo microenvironment, but also simplified chip fabrication, making it more suitable for drug toxicity testing.

The occurrence and development of liver injury is a dynamic process and cannot be correctly characterized using only endpoint measurements. In this regard, by combining the liver chip with other biosensors, real-time monitoring of many cellular parameters can be achieved. Bavli et al. proposed a liver chip device that tracks the dynamics of mitochondrial dysfunction and simulates liver damage in real time. Phosphorescent microprobes are embedded in the liver chip, and continuous electrochemical measurements of glucose and lactose changes are achieved through computer-controlled microfluidic switches. Changes in mitochondria from oxidative phosphorylation to anaerobic glycolysis indicate impaired mitochondrial function to assess changes in cell viability and metabolic function [68] (Figure 1C). In addition, some liver chips have also developed high-throughput rapid monitoring systems to quickly evaluate the efficacy and toxicity of drugs. Riahi et al. [72] developed a microfluidic bead electrochemical immunosensor for long-term continuous measurement of cell-secreted biomarkers, which was used in combination with the liver chip to achieve online monitoring of cell-secreted biomarkers, which not only achieved measurement accuracy but also greatly improved detection efficiency.

The miniaturization and flow-through operation of the microfluidic chip greatly reduces sample consumption, and significantly improves detection reliability, resolution, and sensitivity. Kwon et al. [73] designed a Team chip that can predict liver toxicity based on metabolism. Liver chips that can be used for high-throughput screening not only simplify data collection, but also reduce research costs. In addition, the combination of 3D bioprinting technology and organ chips is a promising research direction. Massa et al. used GelMA hydrogel embedded with HepG2/C3A cells as a scaffold, implanted human umbilical vein endothelial cells (HUVECs) into hollow microchannels to construct a vascular layer, and combined this with 3D bioprinting technology, and developed a perfusion liver chip with a vascular layer. The biomimeticity of the chip was enhanced, and the effect of the endothelial layer on the APAP administration process was simulated. The device is useful for observing and predicting the mechanism of drug circulation toxicity at the microcirculation level [69] (Figure 1D). In addition, Nguyen et al. [74] combined patient-derived primary liver cells with 3D bioprinting technology to effectively simulate Drug-induced liver injury (DILI). Using 3D bioprinting technology to achieve rapid high-throughput production of liver chips or liver tissue will greatly reduce production costs and reduce operational difficulties.

Very recently, the formation of organoids from stem cells has emerged as a focus of research. Combining organoid cultivation with organ chips can better control the organoids and their growth microenvironment, and strengthen the interaction between tissues and multiple organs. The research in this area is still ongoing [75].

\subsection{Brief Summary}

Advanced techniques, including spheroidal culture, co-culture, perfusion, and 3D bioprinting, have been used in liver chip research, and made liver chip mimics more and more realistic. Organoids combined with liver chips show great potential and are the future research directions. In the field of 
hepatotoxicity assessment, the liver chip is promising owing to the advantages of increased accuracy, sensitivity, and the ability to detect dynamics. Liver chip technologies are especially important for China because DILI frequently occurs in China due to wide use of health products and Chinese medicine [76].

\section{Drug Nephrotoxicity Testing by Kidney-on-a-Chip}

\subsection{Overview of Drug-Induced Nephrotoxicity}

Drug-induced nephrotoxicity (DIN) is a poisonous effect of drugs on renal function. In clinical settings, DIN accounts for about $\sim 25 \%$ of the reported severe adverse drug reactions [1]. At present, animal and cell models are the common tools used to detect DIN. Owing to the species differences between animals and humans, and the accuracy of the results of renal toxicity prediction, using animal models is inferior. Cell models often utilize simple 2D cultures and have low sensitivity to many in vivo biomarkers. Recently, the kidney-on-a-chip model has been utilized to test nephrotoxicity, which can realize the co-culture of a variety of cells, the simulation of the in vivo microenvironment, and in vitro biomarker profiling. This type of model has great potential to be developed as a future standard in DIN screening.

\subsection{Kidney-on-a-Chip for Drug Nephrotoxicity Testing}

A common type of kidney-on-a-chip is to culture the renal cells on extracellular matrix (ECM)-coated membranes in a sandwiched structure between the polydimethylsiloxane (PDMS) layer and the microfluidic channel [77-79]. The LeClerc group [78] established their microfluidic kidney chips to study acrolein and ifosfamide nephrotoxicity. Van der Meer's team [38] have integrated TEER (transendothelial resistance) measurements in these platforms to assess the cell barrier functions of the related cells, such as human renal epithelial and dog renal tubular cells. Jang's group [77] measured the cisplatin toxicity and P-Glycoprotein (P-gp) efflux transporter activity on a human proximal tubule chip. Compared with traditional cell models, the results obtained on the chip model are closer to in vivo experiments. This is the first reported nephrotoxicity study using human primary renal tubular cells on an "organ-on-a-chip" platform (Figure 2A). Kim et al. [80] cultured Madin-Darby canine kidney (MDCK) cells on a fibronection-coated porous membrane to construct a sandwich structured PDMS chip and used the model to study the kinetics of gentamicin nephrotoxicity. Through the detection of KIM-1, cell death, ZO-1 expression, and other indicators, it was concluded that high concentration exposure to gentamicin would destroy the tight junctions between MDCK cells, reduce cell viability, and increase membrane permeability, which demonstrated the potential of the kidney chip for drug nephrotoxicity research.

Sakolish's group [81] used immortal cell lines to simulate the function of the glomerulus and proximal tubule (Figure 2B). In addition to providing a shear-stressed culture environment for HK-2 cells, the platform contained a glomerular filter containing HUVECs to provide a more realistic "primary urine" inside the device. Later, the group used such a platform to evaluate the DIN by cisplatin and cyclosporine [82]. The results show that HK-2 cells cultured in this microfluidic device are more sensitive. Musah et al. demonstrated that fluid shear stress could promote the proximal tubular epithelial cells (PTECs) to retain more mature phenotypes and develop a glomerulus-on-a-chip model [82]. Weber and his team [83] combined the single-channel Norvatis microphysiology system (MPS) and the PTECs to reconstruct the physiological function of human proximal tubules in vitro and used this platform to evaluate the nephrotoxicity of polymyxin antibiotics. When PTECs were exposed to polymyxin B, some significant increases in damage signals were observed, including KIM-1 and a group of damage-related miRNAs. The platform can perform safety detection of new compounds and define different toxicological pathway responses of the molecule.

Primary rat kidney cells are also used in current kidney-on-a-chips. Wang's group [84] constructed a glomerular chip that reconstructed part of the kidney function at the organ level to simulate the 
glomerular stimulation in the high glucose environment. The device consists of parallel channels, in which primary glomerular microtissues are arranged, including glomerular endothelial cells, three-dimensional basement membranes, and podocytes. These tissues combine with fluid flow to mimic the glomerular filtration barrier (GFB). Qin et al. [85] cultured primary rat glomerular endothelial cells (GECs) on a microfluidic chip to simulate the selective permeability of the renal barrier and then studied the cadmium-induced nephrotoxicity by detecting the expression of ZO-1 protein by GECs. Qu et al. [86] have constructed a microfluidic platform that mimics nephrons, and the device contains glomerulus, Bowman's capsule, proximal renal lumen, and capillary tubules (Figure 2C). Cisplatin and doxorubicin were added to the "renal blood flow" containing bovine serum albumin, E-cadherin, and vascular endothelial growth factor (VEGF), and other biomarkers were used to record the damage of a variety of primary kidney cells through fluorescence imaging. The results showed that the complex microenvironment built in the device makes kidney cells more sensitive to drug nephrotoxicity, which provided new insights for drug-induced nephrotoxicity detection.
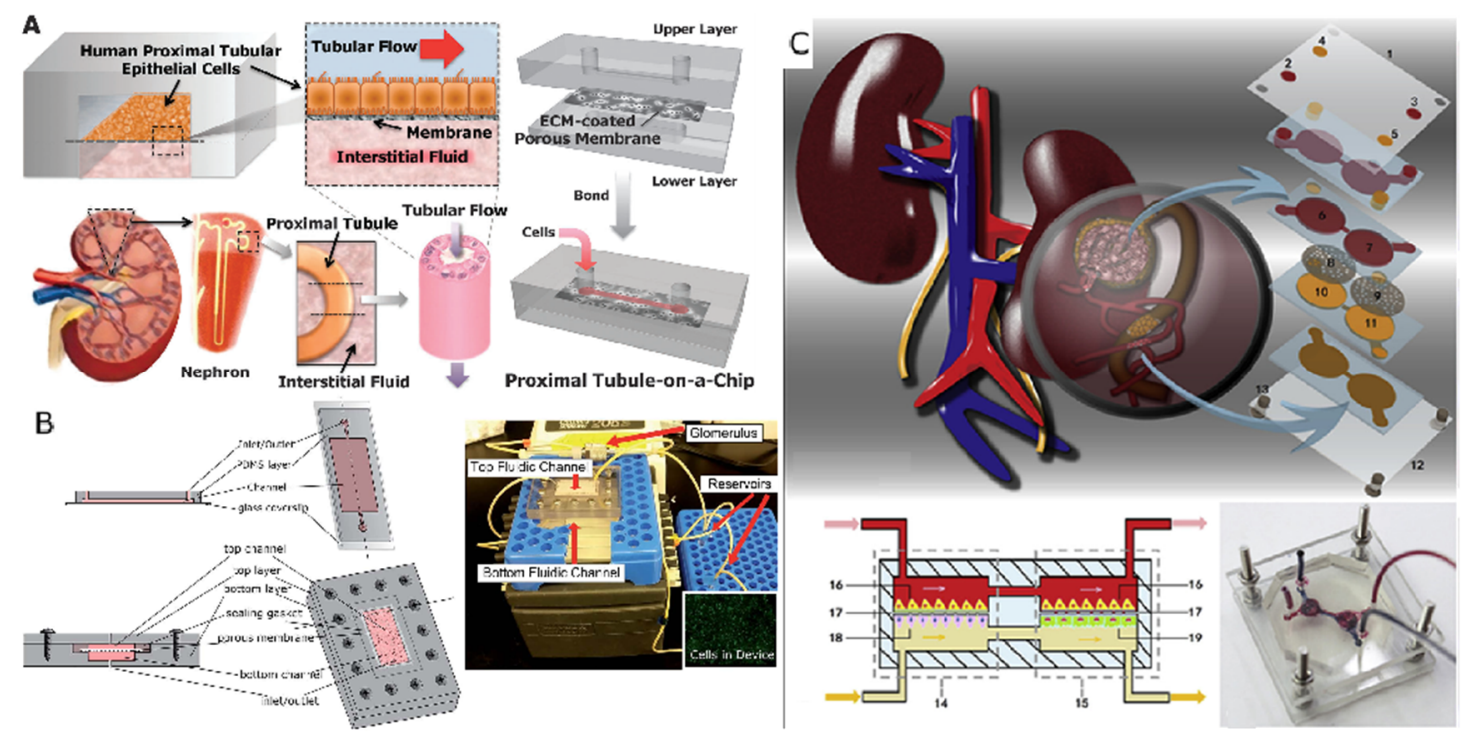

Figure 2. A kidney chip system for drug toxicity testing. (A) Design of the human kidney proximal tubule-on-a-chip [77]. (B) Microfluidic device designs for single channel and multi-channel devices, and the final device assembly with notable features marked [81]. (C) Design for the device contains the glomerulus, Bowman's capsule, proximal renal lumen, and capillary tubules [86].

\subsection{Brief Summary}

Kidney-on-a-chip has shown advantages in nephrotoxicity testing. For instance, the presence of fluid shear stress makes cells more sensitive to the drugs, and the use of primary cells makes the in vitro renal toxicity testing more physiologically relevant. However, high-throughput screening on the kidney chip platform has not yet been achieved. Besides, nephrotoxicity induced by drug metabolites can hardly be studied directly by kidney-on-a-chip. Hyphenation of other organ chips, especially liver chips, is desirable for in-depth study of nephrotoxicity of novel drug candidates. There also is an urgent need to systematically combine in vitro, in vivo, and clinical examinations to develop a set of safe biomarkers that can be effectively and safely detected and treated for reliable diagnosis and monitoring of kidney damage and recovery.

\section{Drug Cardiotoxicity Testing by Heart-on-a-Chip}

\subsection{Overview of Drug-Induced Cardiotoxicity}

"Cardiotoxicity" refers to the direct damage to the heart tissue caused by drugs and the indirect damage by the effects of drugs on hemodynamics, such as causing heart thrombosis [87]. 
"Cardiotoxicity" was first proposed in 1946 to describe the toxic effects of local anesthetics, mercury diuretics, and digitalis on the heart. Later in the 1970s, it was used to describe cardiac complications caused by anthracycline, adriamycin, and 5-fluorouracil [88].

Cardiotoxicity is one of the major reasons of drug failure in clinical testing and withdrawal of drugs from market. For example, drug cardiotoxicity can result in cardiac arrhythmias, therefore the preclinical screening of drug cardiotoxicity is crucial [89]. At present, two-dimensional in vitro cell culture models and animal models are predominant; however, planar cell models cannot restore the complex structure and microenvironment of the heart tissue in the body, and animal models differ from humans in terms of ion channels, biological pathways, and pharmacokinetics. They cannot yet fully reproduce human physiological functions, and in many cases, cannot accurately predict whether drugs have cardiotoxicity to the human body. Other cardiotoxicity screening techniques, such as patch clamps, often involve labor-intensive and invasive cell operations [90]. It is necessary to develop an in vitro model that is more relevant and accurate and simple to operate for cardiac toxicity testing.

\subsection{Heart-on-a-Chip for Drug-Induced Cardiotoxicity Testing}

Electrical stimulation can promote the in vitro maturation of cardiomyocytes. Cardiac chips adopting electrical stimulation have gradually matured. Yang Jianmin et al. [91] reported the first microfluidic devices to achieve cardiac myocytes (CMs) anisotropy (Figure 3A). Qian et al. [92] constructed a cardiac chip that consists of a microelectrode array (MEA) for potential field indication and an interleaved electrode array for conversion. The platform uses transplantation of cardiomyocytes (CMs) derived from human induced pluripotent stem cells (hiPSC-CMs) to measure the electrophysiology and contractility of myocardial cells under physiological conditions and drug stimulation, respectively. The electrical stimulation using microfabricated electrodes (mainly MEA) significantly enhanced the structure and arrangement of cardiac cells. The platform tested the effects of norepinephrine, a clinical drug used to treat hypotension and heart failure. Maoz et al. [47] established a microfluidic device that integrates MEAs and electrodes to verify tissue barrier function by TEER, which helps to understand cardiac pharmacodynamics. The device consisted of an MEA, a PDMS layer, a polyethylene terepthalate (PET) film, a top chip channel, and a TEER electrode. The PET membrane was covered with a layer of HUVECs, and hiPSC-CMs were cultured on the MEA surface. The device can be used to monitor the inflammatory response and the effects of epinephrine drugs on cardiac function. Caluori et al. [93] integrated an electro-mechanical cell biosensor on the heart chip, which could simultaneously detect cardiac excitation-contraction coupling. They used this system to test the response of cells under the stimulation of drugs, and the results show that the system produces a dose-dependent response to calcium channel drugs, isoproterenol, and verapamil, which proves that the device has potential for application in drug screening and drug cardiotoxicity testing. Ville et al. [45] constructed a microelectrode array chip based on human pluripotent stem cell-derived cardiomyocytes and a multi-stage array. This method is capable of constructing layered heart tissue similar to natural myocardium and measuring electrophysiological data. This system proves that hiPSC-CMs has the potential to be used for drug cardiotoxicity screening, by measuring the drug response of hiPSC-CMs in the presence of cardiotoxic prodrugs (terfenadine) and its non-cardiotoxic metabolites (fexofenadine).

In addition to electrical stimulation, there are currently many cardiac chips that attempt to reproduce the annular uniaxial strain in vitro. Marsano et al. [94] developed a cardiac chip with hydrocardial coating, which promoted cardiomyocyte maturation through conductive mechanical stimulation, improved electrical stimulation pacing performance, and enabled analysis of cardiac tissue pacing. The Parker group used muscle thin-film technology (MTF) to construct the heart chip, and further increased the throughput of MTF. This device reflected the effect of isoprenaline, a $\beta$-adrenergic receptor agonist, on the contractility of ventricular CMs in neonatal rats [46]. On the basis of this, the Parker group then assembled flexible thin-film sensors and developed a high-throughput microfluidic device, in which the contractile stress and pulsation rate of 24 cardiac muscle tissues 
could be read at the same time. Recently, a Biowire platform was proposed in which caridac cells were embedded in hydrogels in PDMS microwells, and heart tissue was suspended in holes on two polymer wires, mimicking the growth of muscle fibers in the heart. When they contract, they pull the wires to produce a measurable deflection, which is transformed into a heartbeat signature [95]. In the latest research, Zhao et al. [96] for the first time use a biodegradable, elastic, UV-polymerizable, and rapid-producing poly(octamethylene maleate (anhydride) citrate) (POMaC) polymer material to create a two-dimensional grid for cell growth, called the Biowire II platform. It is a heteropolar cardiac tissue engineered with different atria and ventricles that provides simultaneous quantification of force and $\mathrm{Ca}^{2+}$ transients (Figure 3B).

Although the vast majority of cardiac chip devices mimic the myocardium, studies of cardiovascular models and systems that combine the heart and other organ tissues have been reported in recent years. Ellis et al. [97] developed a microfluidic device that mimics human myocardium and its surrounding microvasculature by spatially controlling the co-culture of CMs and endothelial cells. Kamei et al. [98] reported a soft lithography-based microfluidic device that uses integrated pneumatic valves and pumps to generate a precise fluid flow to simulate the side effects of cancer drugs. The system includes a set of cell culture chambers with a microfluidic system that simulates the blood circulation system and connects various tissue cells. Human healthy heart cells (hCMs) and liver cancer cells (HepG2) are co-cultured in separate chambers (Figure 3C). This device evaluates the side effects of doxorubicin on heart cells, which are caused by HepG2 cells delivering toxic metabolites to heart cells through circulation.

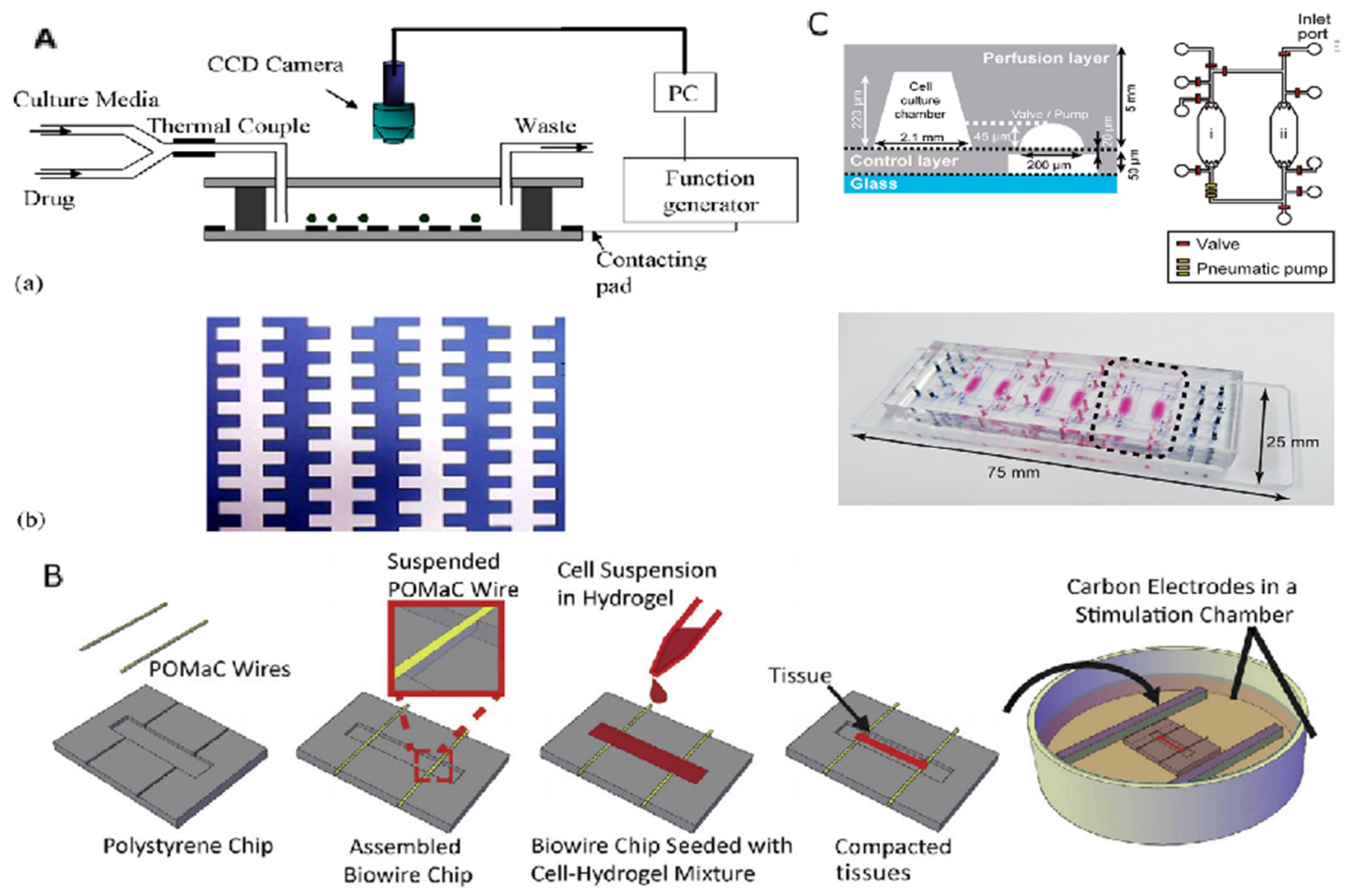

Figure 3. A heart chip system for drug toxicity testing. (A) Schematic of the first microfluidic devices to CMs anisotropy [91]. (B) Representative tissues in the Biowire II platform [96]. (C) Design of the microfluidic device used for integrated heart/cancer-on-a-chip (iHCC) [98].

\subsection{Brief Summary}

Drug-induced cardiotoxicity is a critical issue in drug development. Unfortunately, current in vitro methods lack accuracy in the prediction, judgment, and treatment of cardiotoxicity. Development of microfluidic technology has made the heart chip a new type of in vitro tool, but there are still several 
core issues that need to be resolved, such as accurate real-time imaging which is difficult to achieve due to the high thickness of the chip and suitable biomarkers [99]. The current research focuses on solving these problems by integrating on-chip analytical techniques such as high-performance liquid chromatography, mass spectrometry, and electrophoresis [100]. Another challenge of the cardiac chip is to integrate different types of cells into a single tissue to better simulate the in vivo environment. However, due to the complexity of the in vivo environment and the long-term in vitro culture required for tissue stability, this can be a costly and challenging process. The cardiac chip enables integration of sensing devices, multi-cell co-culture, and 3D tissue formation. It is a new technology with rapid development and great potential, and it can become a new type of pre-clinical drug screening tool to evaluate drug cardiotoxicity.

\section{Drug Neurotoxicity Testing by Nerve-on-a-Chip}

Nerve-on-a-chip still is in its infancy. This section describes the research progress of neurochips, its application in toxicity detection, and research related to neurodegenerative diseases.

\subsection{Research Progress of Neural Chips}

Maher et al. [101] designed a set of microwell structures on a chip, which can achieve a one-to-one correspondence between neuron cells and metal microelectrodes. At the same time, each microwell has a hole through the center and pores around it. Synaptic connections can be established with peripheral neurons. In order to enhance the synaptic connection, Service et al. [102] designed a pattern on the surface of the chip, coated it with a thin layer of diethylenetriamine (DETA) that facilitates the growth of nerve cells. They successfully observed the directional growth of the synapses of the neuron. Maher et al. [101] also designed a chip in which microelectrodes were fabricated to stimulate and detect neuron cells at the same time, using a voltage-sensitive fluorescent dye whose excitation spectrum can change with the membrane potential.

Adhesion of neuron cells on the silicon surface is a key issue in the neural chip fabrication. Fan et al. [103] directly injected hydroxide ions into the silicon surface, thereby enhancing the hydrophilicity of the silicon surface and promoting cell adhesion. Qingjun Liu [104] integrated photo-addressable potential sensors on the neurochip, cultured olfactory sensory neurons on it, and fabricated a bioelectronic nose, which expanded the applications of the neural chip. Kang W et al. [105] integrated microchannels, cell culture chambers, built-in electrodes, and porous substrates in a neurochip that enabled long-term cell culture, differentiation, and transient transfection.

\subsection{Application of Neural Chips in Toxicity Detection}

Schmidt et al. [106] summarized that drug induced neurotoxicity occurs through six pathways, including the blood-brain barrier, lipid-rich structures, energy requirements, synaptic transmission, nerve cell structure, and neurobiochemistry, and toxicological testing methods should include test systems, exposure protocols, test endpoints, and prediction models.

Shichang Liu et al. [107] cultured rat cortical neurons on the surface of the microelectrode array fabricated using neural chip technology, and found that three nanomaterials (nano carbon black, nano $\mathrm{Fe}_{2} \mathrm{O}_{3}$, and nano $\mathrm{TiO}_{2}$ ) can produce neurotoxic effects by interfering with the electrical activity of neural networks. Nierode et al. [108] described high-throughput screening of human neural progenitor cells using a 3D cell culture chip. The microarray chip consisted of two complementary polystyrene chips containing 532 microwells for cell culture. The protein expression, viability, acute toxicity, and antiproliferative effects of 24 compounds were detected based on fluorescence analysis. Kafi et al. [109] grafted a nano-scale film of an arginine-glycine-aspartic acid tripeptide sequence on the surface of the chip for fixation of neurons and facilitated electrochemical measurement. They used this chip to monitor the toxic effects of quantum dots, graphene oxide, and cosmetic compounds.

Zhe Qu et al. [110] tested the toxic effects of nine selected drugs on Sprague Dawley (SD) rat neural stem cells using neurosphere technology. The size of neurospheres varied with toxic chemicals, 
and the results were consistent with the known neurotoxicity of these drugs. Xiannuo Zheng [111] developed a neurochip with a C-type dam structure, and realized long-term continuous observation and photographing of target cells. The toxicology of three different structures of quantum dots (CdTe, $\mathrm{CdTe} / \mathrm{CdS}$, and $\mathrm{CdTe} / \mathrm{CdS} / \mathrm{ZnS}$ ) was studied on the chip platform in terms of the morphological changes, cell survival rate, and cell division and proliferation. Yaqing et al. [112] created a microfluidic chip system to culture human-induced pluripotent stem cell (hiPSCs) derived brain organoids in a controlled manner. The chip was composed of two parallel culture chambers and three independent culture medium channels. The two parallel culture chambers were separated by a central channel. The culture chamber was used for 3D culture and the formation of brain organoids. The central channel was used for perfusion. Apoptosis of brain organoids exposed to nicotine was studied on this platform (Figure 4A). Various biomarkers including TUJ1, SOX2, NESTIN, PAX6, PAX2, ISL1, CTIP2, and TBR1 were detected. Immunohistochemical staining and real-time quantitative PCR were performed. This brain organoid chip provided a universal and attractive platform for studying neurodevelopmental disorders in the early stages of pregnancy, and can be extended to brain disease research and drug testing applications.

\subsection{Neural Chips and Neurodegenerative Diseases}

Alzheimer's disease (AD) is a typical neurodegenerative disease. The accumulation of amyloid-beta $(A \beta)$ is widely accepted as the cause [113]. Park et al. [114] designed and fabricated a concave microwell array in which neurospheres were cultured in dynamic conditions driven by osmotic micropump. The toxic effects of $A \beta$ on nerve cells were measured using static and fluidic conditions. This 3D culture-based microfluidic chip is considered as an in vitro brain model for neurodegenerative diseases and high-throughput drug screening (Figure 4B).

Tang et al. [115] designed a microfluidic chip with an asymmetric side channel connected to the central channel by a series of microslots, and built a model of AD neuron damage using 6-OHDA. Three iridoid glycosides (catalpol, gardenoside and harpagide) were selected to investigate the regenerative effects on injured neurons, which have the potential to facilitate drug screening and optimization of treatment options for neurodegenerative diseases (Figure 4C).

Van de Wijdeven et al. [16] designed a microfluidic chip with open cell chambers and interconnected channels, which was flexible for the adjustment of the number and length of nodes, and direction of the channel, reducing flow induced shear stress on cell to construct a multi-node neural network.

\subsection{Brief Summary}

Drug-induced neurotoxicity is an essential issue in drug development. Unfortunately, current in vitro culture methods lack sensitivity and accuracy in the detection and judgment of neurotoxicity. The development of neural chip technology shows unparalleled advantages in neurotoxicity testing, highly simulating the complex physiological environment of human brain cells, and continuous perfusion can also achieve long-term dynamic culture. However, there is an urgent need to systematically combine in vitro, in vivo and clinical examinations to develop a series of biomarkers that can be safely and effectively detected in order to reliably monitor nerve damage and conduct in-depth research on repairing neurons. Neural chips are a new technology with rapid development and broad prospects that can become a new pre-clinical drug screening tool for evaluating neurotoxicity of drugs, which will definitely have a significant impact on the future survival and quality of life of humans. 


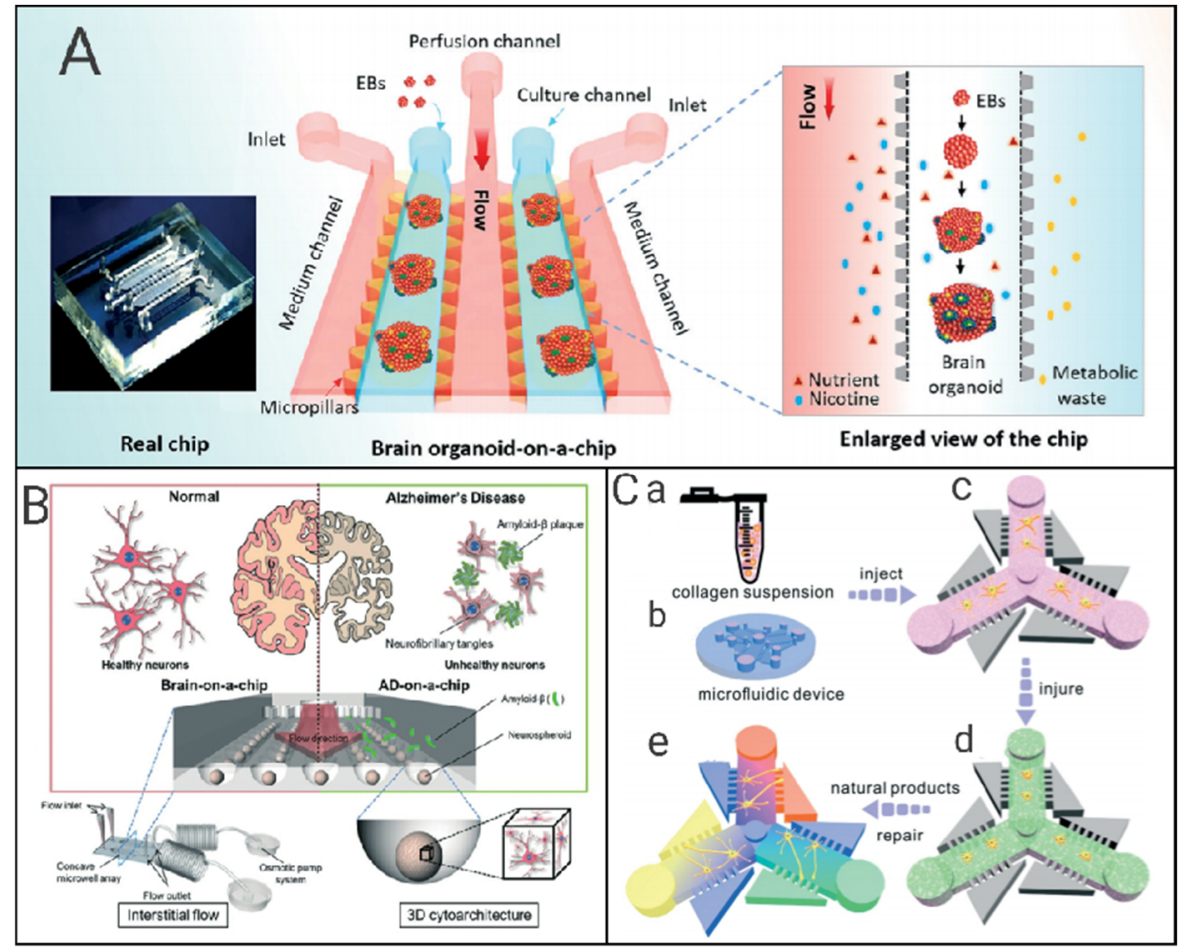

Figure 4. Schematic diagram of the research progress of neural chips. (A) The structure of the human brain organoid-on-a-chip to model prenatal nicotine exposure [112]. (B) Three-dimensional brain-on-a-chip with an interstitial level of flow and its application as an in vitro model of Alzheimer's disease [114]. (C) A 3D microfluidic device to quantify orientational regeneration of injured neurons in AD by natural product concentration gradients [115].

\section{Drug Toxicity Evaluation by Other Organ-on-Chips}

\subsection{Gut-on-a-Chip}

The intestine is an essential site for drug metabolism, and most drugs undergo overall first-pass metabolism in it $[116,117]$. It is crucial to develop reliable in vitro models to study the intestinal metabolism of drugs involving multiple kinds of bacteria. This section will briefly introduce the current application of intestinal chips in drug toxicity testing.

The microfluidic device can provide laminar flow and control the volume of fluids, integrate TEER detection, and co-culture a variety of cells. These advantages allow gut-on-a-chip to overcome the shortcomings of traditional cell models and organoids. Most intestinal chips contain two hollow channels separated by an ECM-coated or polyester-coated polycarbonate porous membrane with immortalized human intestinal epithelial cells cultured on the membrane surface. Kim et al. cultured human intestinal epithelial (Caco-2) cells in a microdevice. Under the action of shear stress, the epithelial cells rapidly polarized, resulting in natural folds, which mimicked the structure of intestinal villi in vitro. Also, they confirmed that typical intestinal microorganisms (Lactobacillus rhamnosus GG) could be cultured in the device for more than a week, which is very similar to humans [118]. Subsequently, this group found that the intestinal villi in the device had particular cell and tissue functions, which were able to secrete mucus and had a robust drug metabolic activity for CYP3A4 [119]. In 2015, the Kim group cultured the human intestinal epithelial cells and some intestinal microorganisms in direct contact with the epithelial cells above the intestinal chip and analyzed the inflammatory mechanism caused by excessive growth of intestinal bacteria [120]. The series of studies above show the potential of intestinal chips in physiopathology and drug gut toxicity studies.

Intestinal chips are often used to study drug metabolism and related diseases. Li's team constructed an intestinal chip on which the intestinal epithelial cells formed a dense cell layer that showed higher 
alkaline phosphatase (ALP) and stress insensitive (SI) gene expression compared to traditional cell models [121]. They used the device to test the metabolic capacity of verapamil and isofluamide, and the results showed that intestinal cells had high levels of CYP450 enzyme expression, which enhanced the metabolism of oral drugs. Claudia et al. constructed a high-throughput intestinal chip device to mimic inflammatory bowel disease (IBD) in vitro (Figure 5A) [122]. Inhibition of crucial inflammation regulators RELA and MYD88 by on-chip adenovirus short hairpin RNA (shRNA) transduction can reduce the IBD phenotype by reducing cytokine production. These results also show the potential of gut-on-a-chip for both efficacy screening and drug toxicity testing.

A complete digestive system chip can be constructed based on the intestinal chip. Haan et al. [123] developed a small cell-free enzymatic digestion system with three microreactors in series to simulate the digestive functions of the mouth, stomach, and small intestine. The nutrients processed by the system are transferred to an intestinal absorption module, which is an intestinal chip containing human intestinal epithelial cells. This study provides new insights for in vitro studies of the digestive system.

\subsection{Lung-on-a-Chip}

During normal inhalation, the pressure in the pleura decreases, and air inhaled into the lungs causes the alveoli to expand, causing the endothelium to dilate the alveolar epithelium and adjacent capillaries. Many drugs can cause pulmonary toxicity, especially some chemotherapy drugs. Pulmonary toxicity can be divided into two categories based on the way lungs are exposed to the poison [124]. Drugs that disrupt the balance of the respiratory system are the major type of lung toxicity. At the same time, manufactured nanoparticles (NPs) that people come into contact with by inhalation can also cause toxic irritation [125]. This section will briefly introduce the application of lung-on-a-chip in studying lung toxicity and related diseases.

Dongeun Huh et al. reconstructed critical functional alveolar-capillary interface in vitro, and they set two lateral micro-chambers into a microfluidic device to simulate pressure-driven stretching of the lungs during breathing [126]. This design can simulate the dynamic mechanical deformation of the alveolar-capillary interface caused by respiratory motion. They also observed that when angiopoietin 1 (Ang-1) was co-administered with IL-2, the pulmonary epithelial cells were stable, and there was almost no vascular leakage caused by IL-2. This result indicates that Ang-1 prevents the formation of acellular gaps and that mechanical strain energy activates transient receptors or potential vanillin 4 (TRPV4) ion channels. This versatile system enables direct visualization and quantitative analysis of various biological processes in intact lung organs, which is impossible with animal models and traditional cell culture models. Later, the team built up a lung-on-a-chip system that can simulate lung function in normal and disease states (Figure 5B) [127], further expanding the application prospects of lung-on-a-chip technology in drug screening and toxicity testing. Zhang et al. designed a lung chip with a sandwich structure, which has three parallel channels. The device was separated by a matrix gel membrane in the middle, and endothelial cells and human alveolar cells were cultured in both channels. They used the device to evaluate the effects of titanium oxide (TiO2) and zinc oxide ( $\mathrm{ZnO})$ nanoparticles on cell morphology, connexin expression, reactive oxygen species (ROS) generation, and epithelial and endothelial cell apoptosis [125]. Yang's group built a nanofiber membrane-supported lung chip and evaluated the toxicity of gefitinib, an anti-tumor drug targeting epidermal growth factor receptor (EGFR) [128]. Felder et al. developed a lung chip and performed a wound healing test on the chip to test the role and physiological circulation of human liver growth factor (rhHGF). The results proved that cyclic mechanical stretching had a significant effect on the wound healing process. The main results of these studies will help us to understand the complex pathogenesis of idiopathic pulmonary fibrosis (IPF) [129].

In summary, several studies conducted on the construction of lung chips obtained results that are more consistent with in vivo tests, demonstrating the potential of this model in studying respiratory disorders and drug screening. 


\subsection{Blood-brain Barrier (BBB)-on-a-Chip}

There are still many microfluidic chips that mimic other human tissues or structures with the potential for drug screening and toxicity testing. This section will briefly introduce the research on BBB-on-a-chip.

The BBB is closely related to drug absorption and metabolism. At the level of brain microvasculature, BBB serves as a highly dynamic and functional interface between the systemic circulation and the central nervous system. Its function is to maintain a stable brain environment and protect the central nervous system. The BBB strictly and accurately regulates the transport of essential molecules and nutrients necessary for neuronal function. From a functional and structural point of view, BBB consists of highly differentiated vascular endothelial cells (VECs), which are arranged in the brain microvasculature [130]. In order to better study the relevant mechanisms of the BBB and the role of drugs through the blood-brain barrier in vitro, the researchers developed a BBB-on-a-chip model using the chip platform. Nicolazzo et al. [131] innovated a microfluidic in vitro model of the blood-brain barrier. Microfluidic blood-brain barrier $(\mu \mathrm{BBB})$ were cultured with $b$.End 3 endothelial cells, both with and without co-cultured C8-D1A astrocytes. Nakagawa et al. [132] proposed a new BBB model, in which primary rat brain endothelial cells, pericytes, and astrocytes were co-cultured (Figure 5C). Booth et al. [133] developed a $\mu$ BBB with a dynamic environment of fluid shear stress and a relatively thin two-cell layer interface. The validity of the model was tested by TEER testing.

Vatine et al. used induced pluripotent stem cell (iPSCs) derived brain microvascular endothelial cells (iBMECs), astrocytes, and neurons to construct a complete human BBB chip. iBMECs form a tight monolayer that expresses cerebrovascular-specific markers [134]. The use of iPSCs from patients with neurological diseases can predict the lack of disease-specific transporters and the disruption of barrier integrity. By combining organ chip technology with human iPSC-derived tissue, the team created a neurovascular unit that can recombine complex blood-brain barrier functions, provide a platform for modeling heritable neurological diseases, and advance drug screening of personalized medicine.

A.

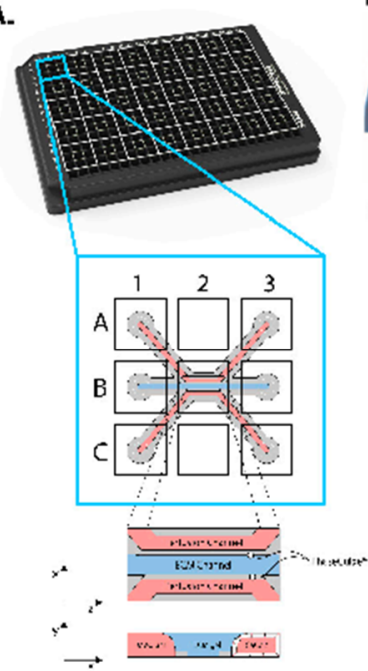

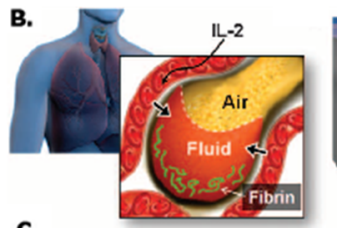

C.

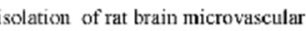
endothelial cells (RBEC)

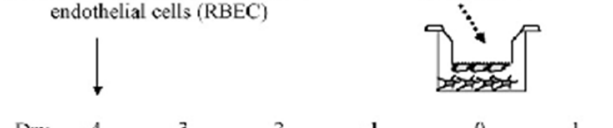

Day -
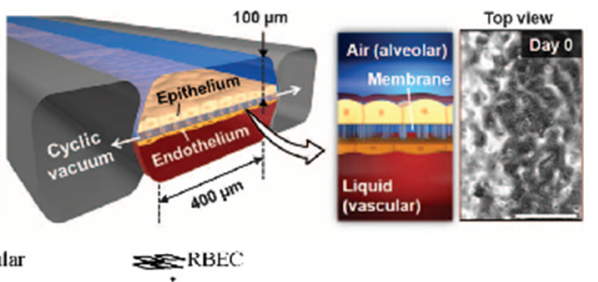
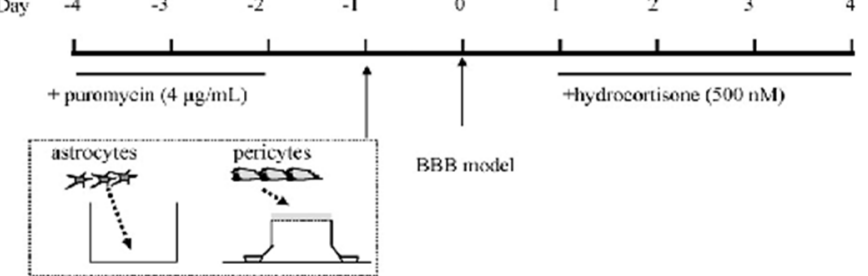

BBB moxiel

Figure 5. Some other-organ-on-a-chip systems for drug toxicity testing. (A) Schematic representation of the 3-lane OrganoPlate gut-on-a-chip model [122]. (B) A microengineered model of human pulmonary edema [127]. (C) Schematic drawing of the preparation of the in vitro blood-brain barrier (BBB) model [132].

\subsection{Brief Summary}

The design principle of the organ-on-a-chip system is to reconstruct the physiological functions of the organ system in vitro. Ideally, the microfluidic chip model can simulate the smallest functional unit of each organ system. In addition to the organs mentioned above, microfluidic chip models of skin [135], vasculature [136], and tumors [137] are also widely used in drug discovery and preclinical 
testing. With further technical development, more and more organs and tissues can be simulated on microfluidic chip models. Although there are still deficiencies in organ size and blood flow conversion [138], this technology has gradually matured.

\section{Drug Toxicity Evaluation by Multi-Organ-on-a-Chip}

\subsection{Liver-Kidney-on-Chip}

Chang et al. built a liver-kidney chip model to detect the renal toxicity of aristolochic acid on humans [139]. They demonstrated that human liver cell-specific metabolism of AA-1 increases its cytotoxicity to human renal proximal tubular epithelial cells, forms aristololactam adducts, and releases kidney injury biomarkers. AA-1 biotransformation into nephrotoxic metabolites through the liver involves nitro reduction followed by sulfate binding. The team determined that the sulfate conjugate of the aristololactam product of AA-1 (AL-1-NOSO3) produced by liver NQO1 in human tissue-based systems is the nephrotoxic form of AA-1. Theobald et al. developed a simple liver-kidney chip model in which liver cells stably grow and express related biomarkers [140]. They applied the system to study the biotransformation and toxicity of aflatoxin $\mathrm{B} 1$ (AFB1) and benzostyrene (B $\alpha \mathrm{P})$, and the interaction of these two drugs with other chemicals. The results show that in this model, the toxicity and metabolic response of drugs can be evaluated in a flow-controlled manner. Later, the team set up a multi-chamber liver-kidney chip to study drug metabolism in vitro [141]. The pump-driven vitamin D3-containing culture medium produced an eluate containing vitamin D3 metabolites through a microfluidic chip, where LC-MS/MS showed strong 25-hydroxyvitamin D accumulation.

\subsection{Other Multi-Organs-on-Chips}

Jong et al. developed a microfluidic device incorporating artificial liver, tumor, and bone marrow in which cells were cultured in hydrogels and microchannels and served as artificial blood vessels to test the cytotoxicity of anticancer drugs. The microfluidic network provides a platform for simulating the pharmacokinetics and pharmacodynamics of drugs in the human body, and the three-dimensional hydrogel provides a tissue environment more similar to physiological requirements [142]. The cytotoxic effect of Tegafur, an oral prodrug of 5-fluorouracil (5-FU), on each cell line, was tested using the micro cell culture analog (mCCA) and compared with a 96-well microtiter plate. The results showed that mCCA was able to reproduce the metabolism of Tegafur to 5-FU in the liver and consequent death of cells by 5 -FU, while the 96-well microtiter plate did not. Oleaga et al. reported a multi-organ-on-a-chip including artificial heart, muscle, neuron, and liver, which could be maintained for 14 days. Computer simulation of the platform established the flow and provided the physiologically required shear stress [143]. After $48 \mathrm{~h}$ of exposure, the toxicity of five drugs in seven days was evaluated. The results obtained were generally consistent with the toxicity results already published from animal experiments and clinical testing. Li's group proposed a new multi-layered organ chip device that can simultaneously assess drug metabolism and its efficacy and cytotoxicity in different organ-specific cells. Four cell lines representing liver, tumors (breast and lung cancer), and healthy tissues (stomach cells) were cultured in separate microcavities in multilayer microdevices [144]. From this study, it can be observed that the multi-organ-on-a-chip can reflect overall toxic effects of drug candidates on the whole body. McAleer et al. investigated the time-dependant pharmacokinetic/pharmacodynamic (PKPD) of tefenadine by a heart-liver system. The team used a metabolizable liver module to convert terfenadine to fexofenadine to regulate this response [145].

\subsection{Brief Summary}

Once the drugs enter the body, they penetrate the tissues through the blood circulation and reach various organs to exert therapeutic or toxic effects. The entire process involves interactions between many organs and tissues. The multi-organ-on-a-chip system can simulate the synergistic effects of multiple organs and build an organ network to study the absorption, distribution, metabolism, 
and elimination of drugs in the body [146] — for example, the liver-renal system and liver-intestine system mentioned above. Multi-organ chips still face particular challenges. For example, the culture conditions for each organ normally vary; however, on a multi-organ chip system, they normally are same. We need to differentiate the cell culture conditions on a multi-organ chip. With the rapid recognition of this issue, people began to discuss good cell culture practice (GCCP) [147] to establish cell quality standards and ensure the integrity and reproducibility of multi-organ chips in vitro. The future multi-organ-on-a-chip system will be more consistent and will be more applied in the fields of drug screening and toxicity detection.

\section{Conclusions and Future Perspective}

In preclinical drug development, using human cells to predict the toxicity of candidate compounds to improve the success rate of clinical trials is a topic that is being explored by almost all major pharmaceutical companies. The Food and Drug Administration (FDA) and drug regulatory agencies in other countries have already being focusing on organ-on-a-chip technology that has the potential to replace animal models in preclinical testing of drugs. Organ-on-a-chip technology can provide a good living environment for cells, tissues, or organs in vitro, and enhance its function and sensitivity to drug stimulation, which is very important in drug screening. Although the organ chips face some challenges in terms of materials, cellular origin, throughput, and validation, they have shown great potential for drug toxicity testing. A key goal of organ-on-a-chip technology in the field of toxicity is to enhance the reproducibility of the results and compare them with clinical data. If consistent results are obtained, this could eventually lead to a new drug toxicity testing paradigm.

Author Contributions: X.Z. and Y.L. (Yong Luo) conceived this review. Y.C., X.H., Y.W., Z.C., Y.L. (Yao Lu), T.L., Y.J. and Z.W. wrote the manuscript. Y.C., X.H., Y.W. designed section structures and produced figures. Y.L. (Yao Lu), T.L. and Z.W. modified the grammar and revised this review. All authors have read and agreed to the published version of the manuscript.

Funding: This research was funded by the National Natural Science Foundation of China (NNSFC) (No. 21675017), the National Key Research and Development Program of China (No. 2017YFC1702001), Shenzhen Fundamental Research and Discipline Layout project (No. JCYJ2018050815247476), the China Postdoctoral Science Foundation (No. 21675017), State Key Laboratory for Managing Biotic and Chemical Threats to the Quality and Safety of Agro-products (No. KF20190108), and Sanming Project of Medicine in Shenzhen (No. SZSM201612049).

Conflicts of Interest: The authors declare no conflict of interest.

\section{References}

1. Barré-Sinoussi, F.O.; Montagutelli, X. Animal models are essential to biological research: Issues and perspectives. Future Sci. OA 2015, 1, FSO63. [CrossRef] [PubMed]

2. Yeo, L.Y.; Hsueh-Chia, C.; Peggy, P.Y.C.; James, R.F. Microfluidic devices for bioapplications. Small 2011, 1, 12-48. [CrossRef] [PubMed]

3. Volpatti, L.R.; Yetisen, A.K. Commercialization of microfluidic devices. Trends Biotechnol. 2014, 7, 347-350. [CrossRef] [PubMed]

4. Zhuang, Q.; Ning, R.; Ma, Y.; Lin, J. Recent developments in microfluidic chip for In vitro cell-based research. Chin. J. Anal. Chem. 2016, 4, 522-532. [CrossRef]

5. Bhatia, S.N.; Ingber, D.E. Microfluidic organs-on-chips. Nat. Biotechnol. 2014, 8, 760-772. [CrossRef]

6. Zhang, B.; Korolj, A.; Lai, B.F.L.; Radisic, M. Advances in organ-on-a-chip engineering. Nat. Rev. Mater. 2018, 8, 257-278. [CrossRef]

7. Hendriks, D.F.G.; Fredriksson Puigvert, L.; Messner, S.; Mortiz, W.; Ingelman-Sundberg, M. Hepatic 3D spheroid models for the detection and study of compounds with cholestatic liability. Sci. Rep. 2016, 6, 35434. [CrossRef]

8. Wang, J.; Zhang, X.; Li, X.; Zhang, Y.; Hou, T.; Wei, L.; Qu, L.; Shi, L.; Liu, Y.; Zou, L.; et al. Anti-gastric cancer activity in three-dimensional tumor spheroids of bufadienolides. Sci. Rep. 2016, 6, 24772. [CrossRef]

9. Zhuang, P.; Sun, A.X.; An, J.; Chua, C.K.; Chew, S.Y. 3D neural tissue models: From spheroids to bioprinting. Biomaterials 2018, 154, 113-133. [CrossRef] 
10. Fatehullah, A.; Tan, S.H.; Barker, N. Organoids as an in vitro model of human development and disease. Nat. Cell Biol. 2016, 3, 246-254. [CrossRef]

11. Park, S.E.; Georgescu, A.; Huh, D. Organoids-on-a-chip. Science 2019, 364, 960-965. [CrossRef] [PubMed]

12. Caplin, J.D.; Granados, N.G.; James, M.R.; Montazami, R.; Hashemi, N. Microfluidic organ-on-a-chip technology for advancement of drug development and toxicology. Adv. Healthc. Mater. 2015, 10, 1426-1450. [CrossRef] [PubMed]

13. Knowlton, S.; Tasoglu, S. A bioprinted liver-on-a-chip for drug screening applications. Trends Biotechnol. 2016, 9, 681-682. [CrossRef] [PubMed]

14. Faria, J.; Ahmed, S.; Gerritsen, K.G.F.; Mihaila, S.M.; Masereeuw, R. Kidney-based In vitro models for drug-induced toxicity testing. Arch. Toxicol. 2019, 93, 3397-3418. [CrossRef] [PubMed]

15. Conant, G.; Lai, B.F.L.; Lu, R.X.Z.; Korolj, A.; Wang, E.Y.; Radisic, M. High-content assessment of cardiac function using heart-on-a-chip devices as drug screening model. Stem Cell Rev. Rep. 2017, 3, 335-346. [CrossRef] [PubMed]

16. van de Wijdeven, R.; Ramstad, O.H.; Bauer, U.S.; Halaas, O.; Sandvig, A.; Sandvig, I. Structuring a multi-nodal neural network In vitro within a novel design microfluidic chip. Biomed. Microdevices 2018, 1, 9. [CrossRef] [PubMed]

17. Rezaei Kolahchi, A.; Khadem Mohtaram, N.; Pezeshgi Modarres, H.; Mohammadi, M.; Geraili, A.; Jafari, P.; Akbari, M.; Sanati-Nezhad, A. Microfluidic-based multi-organ platforms for drug discovery. Micromachines 2016, 9, 162. [CrossRef]

18. Zheng, F.; Fu, F.; Cheng, Y.; Wang, C.; Zhao, Y.; Gu, Z. Organ-on-a-chip systems: Microengineering to biomimic living systems. Small 2016, 17, 2253-2282. [CrossRef]

19. Hamilton, L.A.; Collins-Yoder, A.; Collins, R.E. Drug-induced liver injury. AACN Adv. Crit. Care 2016, 4, 430-440. [CrossRef]

20. Thulin, P.; Hornby, R.J.; Auli, M.; Nordahl, G.; Antoine, D.J.; Starkey Lewis, P.; Goldring, C.E.; Park, B.K.; Prats, N.; Glinghammar, B.; et al. A longitudinal assessment of miR-122 and GLDH as biomarkers of drug-induced liver injury in the rat. Biomarkers 2017, 5, 461-469. [CrossRef]

21. Huebener, P.; Pradere, J.; Hernandez, C.; Gwak, G.; Caviglia, J.M.; Mu, X.; Loike, J.D.; Jenkins, R.E.; Antoine, D.J.; Schwabe, R.F. The HMGB1/RAGE axis triggers neutrophil-mediated injury amplification following necrosis. J. Clin. Investig. 2015, 2, 539-550. [CrossRef] [PubMed]

22. Church, R.J.; Watkins, P.B. The transformation in biomarker detection and management of drug-induced liver injury. Liver Int. 2017, 37, 1582-1590. [CrossRef]

23. Mcgill, M.R.; Sharpe, M.R.; Williams, C.D.; Taha, M.; Jaeschke, H. The mechanism underlying acetaminophen-induced hepatotoxicity in humans and mice involves mitochondrial damage and nuclear DNA fragmentation. J. Clin. Investig. 2012, 4, 1574-1583. [CrossRef] [PubMed]

24. Church, R.J.; Ublick, G.A.K.; Aubrecht, J.; Bonkovsky, H.L.; Chalasani, N.; Fontana, R.J.; Goepfert, J.C.; Hackman, F.; King, N.M.P.; Kirby, S. Candidate biomarkers for the diagnosis and prognosis of drug-induced liver injury: An international collaborative effort. Hepatology 2019, 69, 760-773. [CrossRef] [PubMed]

25. Desai, P.K.; Tseng, H.; Souza, G.R. Assembly of Hepatocyte Spheroids Using Magnetic 3D Cell Culture for CYP450 Inhibition/Induction. Int. J. Mol. Sci. 2017, 18, 1085. [CrossRef] [PubMed]

26. Wang, K.; Zhang, S.; Marzolf, B.; Troisch, P.; Brightman, A.; Hu, Z.; Hood, L.E.; Galas, D.J. Circulating microRNAs, potential biomarkers for drug-induced liver injury. Proc. Natl. Acad. Sci. USA 2009, 11, 4402-4407. [CrossRef]

27. Mikus, M.; Drobin, K.; Gry, M.; Bachmann, J.; Lindberg, J.; Yimer, G.; Aklillu, E.; Makonnen, E.; Aderaye, G.; Roach, J. Elevated levels of circulating CDH5 and FABP1 in association with human drug-induced liver injury. Liver Int. 2017, 37, 132-140. [CrossRef]

28. Swan, S.K. The search continues-An ideal marker of GFR. Clin. Chem. 1997, 6, 913-914. [CrossRef]

29. Rewa, O.; Bagshaw, S.M. Acute kidney injury-Epidemiology, outcomes and economics. Nat. Rev. Nephrol. 2014, 10, 193-207. [CrossRef]

30. Vlasakova, K.; Erdos, Z.; Troth, S.P.; McNulty, K.; Chapeau-Campredon, V.; Mokrzycki, N.; Muniappa, N.; $\mathrm{Gu}$, Y.Z.; Holder, D.; Bailey, W.J. Evaluation of the relative performance of 12 urinary biomarkers for renal safety across 22 rat sensitivity and specificity studies. Toxicol. Sci. Off. J. Soc. Toxicol. 2014, 1, 3-20. [CrossRef]

31. George, B.; Joy, M.S.; Aleksunes, L.M. Urinary protein biomarkers of kidney injury in patients receiving cisplatin chemotherapy. Exp. Biol. Med. 2018, 243, 272-282. [CrossRef] 
32. Katagiri, D.; Hamasaki, Y.; Doi, K.; Negishi, K.; Noiri, E. Interstitial renal fibrosis due to multiple cisplatin treatments is ameliorated by semicarbazide-sensitive amine oxidase inhibition. Kidney Int. 2015, 2, 374-385. [CrossRef]

33. Liu, X.; Guan, Y.; Xu, S.; Li, Q.; Sun, Y.; Han, R.; Jiang, C. Early predictors of acute kidney injury: A narrative review. Kidney Blood Press. Res. 2016, 5, 680-700. [CrossRef]

34. Pianta, T.J.; Pickering, J.W.; Succar, L.; Chin, M.; Davidson, T.; Buckley, N.A.; Mohamed, F.; Endre, Z.H. Dexamethasone modifies cystatin c-based diagnosis of acute kidney injury during cisplatin-based chemotherapy. Kidney Blood Press Res. 2017, 1, 62-75. [CrossRef] [PubMed]

35. Huang, J.X.; Blaskovich, M.A.; Cooper, M.A. Cell- and biomarker-based assays for predicting nephrotoxicity. Expert Opin. Drug Metab. Toxicol. 2014, 12, 1621-1635. [CrossRef] [PubMed]

36. Wu, C.Y.; Yang, H.Y.; Chien, H.P.; Tseng, M.H.; Huang, J.L. Urinary clusterin-A novel urinary biomarker associated with pediatric lupus renal histopathologic features and renal survival. Pediatr. Nephrol. 2018, 33, 1189-1198. [CrossRef]

37. Chapman, A.B.; Devuyst, O.; Eckardt, K.U.; Gansevoort, R.T. Autosomal-dominant polycystic kidney disease (ADPKD): Executive summary from a kidney disease: Improving global outcomes (KDIGO) controversies conference. Kidney Int. 2015, 88, 17-27. [CrossRef]

38. Odijk, M.; van der Meer, A.D.; Levner, D.; Kim, H.J.; van der Helm, M.W.; Segerink, L.I.; Frimat, J.; Hamilton, G.A.; Ingber, D.E.; van den Berg, A. Measuring direct current trans-epithelial electrical resistance in organ-on-a-chip microsystems. Lab Chip 2015, 3, 745-752. [CrossRef]

39. Saikumar, J.; Hoffmann, D.; Kim, T.M.; Gonzalez, V.R.; Zhang, Q.; Goering, P.L.; Brown, R.P.; Bijol, V.; Park, P.J.; Waikar, S.S. Expression, circulation, and excretion profile of microRNA-21, -155, and -18a following acute kidney injury. Toxicol. Sci. 2012, 2, 256-267. [CrossRef] [PubMed]

40. Ewer, M.S.; Ali, M.K.; Mackay, B.; Wallace, S.; Valdivieso, M.; Legha, S.S.; Benjamin, R.S.; Haynie, T.P. A comparison of cardiac biopsy grades and ejection fraction estimations in patients receiving adriamycin. J. Clin. Oncol. 1984, 2, 112-117. [CrossRef] [PubMed]

41. Wallace, K.B.; Hausner, E.; Herman, E.; Holt, G.D.; MacGregor, J.T.; Metz, A.L.; Murphy, E.; Rosenblum, I.Y.; Sistare, F.D.; York, M.J. Serum troponins as biomarkers of drug-induced cardiac toxicity. Toxicol. Pathol. 2004, 1, 106-121. [CrossRef] [PubMed]

42. Causey, M.W.; Niten Singh, M.D. Clinical implications of B-type Natriuretic Peptide (BNP) and N-terminal proBNP (NT-proBNP) in the care of the vascular surgery patient. Semin. Vasc. Surg. 2015, 27, 143-147. [CrossRef] [PubMed]

43. Tan, L.; Lyon, A.R. Role of biomarkers in prediction of cardiotoxicity during cancer treatment. Curr. Treat. Options Cardiovasc. Med. 2018, 20, 55. [CrossRef] [PubMed]

44. Marta, O.P.O.; Gurda, D.; Fedoruk-Wyszomirska, A.; Smolarek, I.; Wyszko, E. Circulating microRNAs in cardiovascular diseases. Acta Biochim. Pol. 2016, 4, 725-729.

45. Kujala, V.J.; Pasqualini, F.S.; Goss, J.A.; Nawroth, J.C.; Parker, K.K. Laminar ventricular myocardium on a microelectrode array-based chip. J. Mater. Chem. B 2016, 2, 3534-3543. [CrossRef]

46. Agarwal, A.; Goss, J.A.; Cho, A.; McCain, M.L.; Parker, K.K. Microfluidic heart on a chip for higher throughput pharmacological studies. Lab Chip 2013, 18, 3599. [CrossRef]

47. Maoz, B.M.; Herl, A.; Henry, O.Y.F.; Leineweber, W.; Yadid, M.; Doyle, J.; Mannix, R.; Kujala, V.; Fitzgerald, E.A.; Parker, K.K. Organs-on-chips with combined multi-electrode array and transepithelial electrical resistance measurement capabilities. Lab Chip 2017, 17, 2294-2302. [CrossRef]

48. Higuchi, M.; Virginia, M.Y.L.; John, Q.T. Tau and axonopathy in neurodegenerative disorders. Neuromol. Med. 2002, 2, 131-150. [CrossRef]

49. Siman, R.; Toraskar, N.; Dang, A.; McNeil, E.; McGarvey, M.; Plaum, J.; Maloney, E.; Grady, M.S. A panel of neuron-enriched proteins as markers for traumatic brain injury in humans. J. Neurotrauma 2009, 11, 1867-1877. [CrossRef]

50. Martinez, B.; Peplow, P.V. MicroRNAs as diagnostic markers and therapeutic targets for traumatic brain injury. Neural Regen. Res. 2017, 12, 1749-1761.

51. Lescuyer, P.; Allard, L.; Zimmermann-Ivol, C.G.; Burgess, J.A.; Hochstrasser, D.F. Identification of post-mortem cerebrospinal fluid proteins as potential biomarkers of ischemia and neurodegeneration. Proteomics 2004, 8 , 2234-2241. [CrossRef] [PubMed] 
52. Salehpoor, F.; Meshkini, A.; Razmgiri, A.; Mahdkhah, A. Prognostic serum factors in patients with traumatic brain injury: A systematic review. Neurosurg. Q. 2016, 1, 19-36. [CrossRef]

53. Oliver, J.; Abbas, K.; Lightfoot, J.; Baskin, K.; Collins, B.; Wier, D.; Bramhall, J.; Huang, J.; Puschett, J. Comparison of neurocognitive testing and the measurement of marinobufagenin in mild traumatic brain injury: A preliminary report. J. Exp. Neurosci. 2015, 9, 67-72. [CrossRef] [PubMed]

54. Carr, D.F.; Ayehunie, S.; Davies, A.; Duckworth, C.A.; French, S.; Hall, N.; Hussain, S.; Mellor, H.R.; Norris, A.; Park, B.K.; et al. Towards better models and mechanistic biomarkers for drug-induced gastrointestinal injury. Pharmacol. Ther. 2017, 172, 181-194. [CrossRef] [PubMed]

55. Zhou, M.; Liu, Y.; Duan, Y. Breath biomarkers in diagnosis of pulmonary diseases. Clin. Chim. Acta 2012, 21-22, 1770-1780. [CrossRef] [PubMed]

56. Muller, T. The cellular stress response induced by aqueous extracts of cigarette smoke is critically dependent on the intracellular glutathione concentration. Carcinogenesis 1998, 5, 797-801. [CrossRef]

57. Stolarek, R.; Bialasiewicz, P.; Krol, M.; Nowak, D. Breath analysis of hydrogen peroxide as a diagnostic tool. Clin. Chim. Acta 2010, 411, 1849-1861. [CrossRef]

58. Phillips, M.; Cataneo, R.N.; Greenberg, J.; Grodman, R.; Gunawardena, R.; Naidu, A. Effect of oxygen on breath markers of oxidative stress. Eur. Respir. J. 2003, 1, 48-51. [CrossRef]

59. Henry, O.Y.F.; Villenave, R.; Cronce, M.J.; Leineweber, W.D.; Benz, M.A.; Ingber, D.E. Organs-on-chips with integrated electrodes for trans-epithelial electrical resistance (TEER) measurements of human epithelial barrier function. Lab Chip 2017, 13, 2264-2271. [CrossRef]

60. Hartung, T. Toxicology for the twenty-first century. Nature 2009, 7252, 208-212. [CrossRef]

61. Han, W.; Wu, Q.; Zhang, X.; Duan, Z. Innovation for hepatotoxicity in vitro research models: A review. J. Appl. Toxicol. 2019, 1, 146-162. [CrossRef] [PubMed]

62. Bhise, N.S.; Manoharan, V.; Massa, S.; Tamayol, A.; Ghaderi, M.; Miscuglio, M.; Lang, Q.; Shrike, Z.Y.; Shin, S.R.; Calzone, G.; et al. A liver-on-a-chip platform with bioprinted hepatic spheroids. Biofabrication 2016, 8, 14101. [CrossRef]

63. Zuchowska, A.; Kwapiszewska, K.; Chudy, M.; Dybko, A.; Brzozka, Z. Studies of anticancer drug cytotoxicity based on long-term HepG2 spheroid culture in a microfluidic system. Electrophoresis 2017, 8, 1206-1216. [CrossRef] [PubMed]

64. Kostadinova, R.; Boess, F.; Applegate, D.; Suter, L.; Weiser, T.; Singer, T.; Naughton, B.; Roth, A. A long-term three dimensional liver co-culture system for improved prediction of clinically relevant drug-induced hepatotoxicity. Toxicol. Appl. Pharm. 2013, 1, 1-16. [CrossRef] [PubMed]

65. Ma, C.; Zhao, L.; Zhou, E.; Xu, J.; Shen, S.; Wang, J. On-chip construction of liver lobule-like microtissue and its application for adverse drug reaction assay. Anal. Chem. 2016, 3, 1719-1727. [CrossRef]

66. Jang, K.; Otieno, M.A.; Ronxhi, J.; Lim, H.; Ewart, L.; Kodella, K.R.; Petropolis, D.B.; Kulkarni, G.; Rubins, J.E.; Conegliano, D.; et al. Reproducing human and cross-species drug toxicities using a liver-chip. Sci. Transl. Med. 2019, 517, x5516. [CrossRef]

67. Yu, F.; Deng, R.; Hao Tong, W.; Huan, L.; Chan Way, N.; IslamBadhan, A.; Iliescu, C.; Yu, H. A perfusion incubator liver chip for 3D cell culture with application on chronic hepatotoxicity testing. Sci. Rep. 2017, 7, 14528. [CrossRef]

68. Bavli, D.; Prill, S.; Ezra, E.; Levy, G.; Cohen, M.; Vinken, M.; Vanfleteren, J.; Jaeger, M.; Nahmias, Y. Real-time monitoring of metabolic function in liver-on-chip microdevices tracks the dynamics of mitochondrial dysfunction. Proc. Natl. Acad. Sci. USA 2016, 16, E2231-E2240. [CrossRef]

69. Massa, S.; Sakr, M.A.; Seo, J.; Bandaru, P.; Arneri, A.; Bersini, S.; Zare-Eelanjegh, E.; Jalilian, E.; Cha, B.; Antona, S.; et al. Bioprinted 3D vascularized tissue model for drug toxicity analysis. BiomicrofluIdics 2017, 4, 44109. [CrossRef]

70. Deng, J.; Zhang, X.; Chen, Z.; Luo, Y.; Lu, Y.; Liu, T.; Wu, Z.; Jin, Y.; Zhao, W.; Lin, B. A cell lines derived microfluidic liver model for investigation of hepatotoxicity induced by drug-drug interaction. Biomicrofluidic 2019, 2, 24101. [CrossRef]

71. Jang, M.; Neuzil, P.; Volk, T.; Manz, A.; Kleber, A. On-chip three-dimensional cell culture in phaseguides improves hepatocyte functionsin vitro. Biomicrofluidic 2015, 3, 34113. [CrossRef] [PubMed] 
72. Riahi, R.; Shaegh, S.A.M.; Ghaderi, M.; Zhang, Y.S.; Shin, S.R.; Aleman, J.; Massa, S.; Kim, D.; Dokmeci, M.R.; Khademhosseini, A. Automated microfluidic platform of bead-based electrochemical immunosensor integrated with bioreactor for continual monitoring of cell secreted biomarkers. Sci. Rep. 2016, 6, 24598. [CrossRef] [PubMed]

73. Kwon, S.J.; Lee, D.W.; Shah, D.A.; Ku, B.; Jeon, S.Y.; Solanki, K.; Ryan, J.D.; Clark, D.S.; Dordick, J.S.; Lee, M. High-throughput and combinatorial gene expression on a chip for metabolism-induced toxicology screening. Nat. Commun. 2014, 5, 3739. [CrossRef] [PubMed]

74. Nguyen, D.G.; Funk, J.; Robbins, J.B.; Crogan-Grundy, C.; Presnell, S.C.; Singer, T.; Roth, A.B. Bioprinted 3D primary liver tissues allow assessment of organ-level response to clinical drug induced toxicity in vitro. PLOS ONE 2016, 7, e158674. [CrossRef]

75. Prior, N.; Inacio, P.; Huch, M. Liver organoids: From basic research to therapeutic applications. Gut 2019, 68, 2228-2237. [CrossRef]

76. Shen, T.; Liu, Y.; Shang, J.; Xie, Q.; Li, J.; Yan, M.; Xu, J.; Niu, J.; Liu, J.; Watkins, P.B.; et al. Incidence and Etiology of Drug-Induced Liver Injury in Mainland China. Gastroenterology 2019, 156, 2230-2241.e11. [CrossRef]

77. Jang, K.; Mehr, A.P.; Hamilton, G.A.; McPartlin, L.A.; Chung, S.; Suh, K.; Ingber, D.E. Human kidney proximal tubule-on-a-chip for drug transport and nephrotoxicity assessment. Integr. Biol. 2013, 9, 1119-1129. [CrossRef]

78. Snouber, L.C.; Letourneur, F.; Chafey, P.; Broussard, C.; Monge, M.; Legallais, C.; Leclerc, E. Analysis of transcriptomic and proteomic profiles demonstrates improved madin-darby canine kidney cell function in a renal microfluidic biochip. Biotechnol. Prog. 2012, 2, 474-484. [CrossRef]

79. Ferrell, N.; Ricci, K.B.; Groszek, J.; Marmerstein, J.T.; Fissell, W.H. Albumin handling by renal tubular epithelial cells in a microfluidic bioreactor. Biotechnol. Bioeng. 2012, 3, 797-803. [CrossRef]

80. Kim, S.; LesherPerez, S.C.; Kim, B.C.C.; Yamanishi, C.; Labuz, J.M.; Leung, B.; Takayama, S. Pharmacokinetic profile that reduces nephrotoxicity of gentamicin in a perfused kidney-on-a-chip. Biofabrication 2016, 1, 15021. [CrossRef]

81. Sakolish, C.M.; Mahler, G.J. A novel microfluidic device to model the human proximal tubule and glomerulus. RSC Adv. 2017, 8, 4216-4225. [CrossRef]

82. Sakolish, C.M.; Philip, B.; Mahler, G.J. A human proximal tubule-on-a-chip to study renal disease and toxicity. Biomicrofluidics 2019, 1, 14107. [CrossRef] [PubMed]

83. Weber, E.J.; Lidberg, K.A.; Wang, L.; Bammler, T.K.; MacDonald, J.W.; Li, M.J.; Redhair, M.; Atkins, W.M.; Tran, C.; Hines, K.M.; et al. Human kidney on a chip assessment of polymyxin antibiotic nephrotoxicity. JCI Insight 2018, 3. [CrossRef] [PubMed]

84. Wang, L.; Tao, T.; Su, W.; Yu, H.; Yu, Y.; Qin, J. A disease model of diabetic nephropathy in a glomerulus-on-a-chip microdevice. Lab Chip 2017, 10, 1749-1760. [CrossRef] [PubMed]

85. Li, Z.; Jiang, L.; Tao, T.; Su, W.; Guo, Y.; Yu, H.; Qin, J. Assessment of cadmium-induced nephrotoxicity using a kidney-on-a-chip device. Toxicol. Res. 2017, 3, 372-380. [CrossRef] [PubMed]

86. Qu, Y.; An, F.; Luo, Y.; Lu, Y.; Liu, T.; Zhao, W.; Lin, B. A nephron model for study of drug-induced acute kidney injury and assessment of drug-induced nephrotoxicity. Biomaterials 2018, 155, 41-53. [CrossRef]

87. Brana, I.; Tabernero, J. Cardiotoxicity. Ann. Oncol. 2010, 7, i173-i179. [CrossRef]

88. Chung, R.; Ghosh, A.K.; Banerjee, A. Cardiotoxicity: Precision medicine with imprecise definitions. Open Heart 2018, 2, e774. [CrossRef]

89. Rajasingh, S.; Isai, D.G.; Samanta, S.; Zhou, Z.; Dawn, B.; Kinsey, W.H.; Czirok, A.; Rajasingh, J. Manipulation-free cultures of human iPSC-derived cardiomyocytes offer a novel screening method for cardiotoxicity. Acta Pharm. Sin. 2018, 10, 1590-1603. [CrossRef]

90. Doherty, K.R.; Talbert, D.R.; Trusk, P.B.; Moran, D.M.; Shell, S.A.; Bacus, S. Structural and functional screening in human induced-pluripotent stem cell-derived cardiomyocytes accurately identifies cardiotoxicity of multiple drug types. Toxicol. Appl. Pharm. 2015, 1, 51-60. [CrossRef]

91. Yang, M.; Zhang, X. Electrical assisted patterning of cardiac myocytes with controlled macroscopic anisotropy using a microfluidic dielectrophoresis chip. Sens. Actuators A Phys. 2007, 1, 73-79. [CrossRef]

92. Qian, F.; Huang, C.; Lin, Y.D.; Ivanovskaya, A.N.; O’Hara, T.J.; Booth, R.H.; Creek, C.J.; Enright, H.A.; Soscia, D.A.; Belle, A.M. Simultaneous electrical recording of cardiac electrophysiology and contraction on chip. Lab Chip 2017, 10, 10-1039. [CrossRef] [PubMed] 
93. Caluori, G.; Pribyl, J.; Pesl, M.; Jelinkova, S.; Rotrekl, V. Non-invasive electromechanical cell-based biosensors for improved investigation of 3D cardiac models. Biosens. Bioelectron. 2019, 124-125, 129-135. [CrossRef] [PubMed]

94. Marsano, A.; Conficconi, C.; Lemme, M.; Occhetta, P.; Gaudiello, E.; Votta, E.; Cerino, G.; Redaelli, A.; Rasponi, M. Beating heart on a chip: A novel microfluidic platform to generate functional 3D cardiac microtissues. Lab Chip 2016, 3, 599-610. [CrossRef] [PubMed]

95. Nunes, S.S.; Miklas, J.W.; Liu, J.; Aschar-Sobbi, R.; Xiao, Y.; Zhang, B.; Jiang, J.; Massé, S.; Gagliardi, M.; Hsieh, A.; et al. Biowire: A platform for maturation of human pluripotent stem cell—derived cardiomyocytes. Nat. Methods 2013, 8, 781-787. [CrossRef]

96. Zhao, Y.; Rafatian, N.; Feric, N.T.; Cox, B.J.; Radisic, M. A platform for generation of chamber-specific cardiac tissues and disease modeling. Cell 2019, 176, 913-927.e18. [CrossRef]

97. Ellis, B.W.; Acun, A.; Can, U.I.; Zorlutuna, P. Human iPSC-derived myocardium-on-chip with capillary-like flow for personalized medicine. Biomicrofluidics 2017, 2, 845-856. [CrossRef]

98. Kamei, K.I.; Kato, Y.; Hirai, Y.; Ito, S.; Satoh, J.; Oka, A.; Tsuchiya, T.; Yong, C.; Tabata, O. Integrated heart/cancer on a chip to reproduce the side effects of anti-cancer drugs in vitro. RSC Adv. 2017, 58, 36777-36786. [CrossRef]

99. Beulig, R.J.; Warias, R.; Heiland, J.J.; Ohla, S.; Zeitler, K.; Belder, D. A droplet-chip/mass spectrometry approach to study organic synthesis at nanoliter scale. Lab Chip 2017, 17, 1996-2002. [CrossRef]

100. Maschmeyer, I.; Lorenz, A.K.; Schimek, K.; Hasenberg, T.; Ramme, A.P.; Hubner, J.; Lindner, M.; Drewell, C.; Bauer, S.; Thomas, A.; et al. A four-organ-chip for interconnected long-term co-culture of human intestine, liver, skin and kidney equivalents. Lab Chip 2015, 12, 2688-2699. [CrossRef]

101. Maher, M.; Wright, J.; Pine, J.; Tai, Y. A Microstructure for Interfacing with Neurons: The Neurochip; IEEE: Piscataway, NJ, USA, 1998; pp. 1698-1702.

102. Service, R.F. Neurons and silicon get intimate. Science 1999, 5414, 578-579. [CrossRef] [PubMed]

103. Fan, Y.W.; Cui, F.Z.; Chen, L.N.; Zhai, Y.; Xu, Q.Y. Improvement of neural cell adherence to silicon surface by hydroxyl ion implantation. Surf. Coat. Technol. 2000, 1, 355-359. [CrossRef]

104. Liu, Q.; Cai, H.; Xu, Y.; Li, Y.; Li, R.; Wang, P. Olfactory cell-based biosensor: A first step towards a neurochip of bioelectronic nose. Biosens. Bioelectron. 2006, 2, 318-322. [CrossRef] [PubMed]

105. Kang, W.; Giraldo-Vela, J.P.; Nathamgari, S.S.; McGuire, T.; McNaughton, R.L.; Kessler, J.A.; Espinosa, H.D. Microfluidic device for stem cell differentiation and localized electroporation of postmitotic neurons. Lab Chip 2014, 23, 4486-4495. [CrossRef] [PubMed]

106. Schmidt, B.Z.; Lehmann, M.; Gutbier, S.; Nembo, E.; Noel, S.; Smirnova, L.; Forsby, A.; Hescheler, J.; Avci, H.X. Thomas Hartung. In vitro acute and developmental neurotoxicity screening an overview of cellural platforms and high-throughput technical possibilities. Arch. Toxicol. 2017, 91, 1-33. [CrossRef] [PubMed]

107. Liu, S.C.; Yang, Z. Study on the changes of the electrical activity of neural networks by nanomaterials based on the microelectrode array neural chip. Tianjin Med. J. 2011, 39, 135.

108. Nierode, G.J.; Perea, B.C.; McFarland, S.K.; Pascoal, J.F.; Clark, D.S.; Schaffer, D.V.; Dordick, J.S. High-throughput toxicity and phenotypic screening of 3D human neural progenitor cell cultures on a microarray chip platform. Stem Cell Rep. 2016, 5, 970-982. [CrossRef]

109. Kafi, M.A.; Cho, H.Y.; Choi, J.W. Neural cell chip based electrochemical detection of nanotoxicity. Nanomaterials 2015, 3, 1181-1199. [CrossRef]

110. Qu, Z.; Lv, J.J.; Zang, S.; Geng, X.C.; Li, B.; Zhao, D.M. Study on neurotoxicity model of SD rat neural stem cell evaluation drug. China Pharm. Aff. 2018, 32, 1079-1087.

111. Zheng, X.N. Study on Cytotoxicity of Quantum Dots based on Cell Chip Platform. Master's Thesis, Fudan University, Shanghai, China, 2010.

112. Wang, Y.; Wang, L.; Zhu, Y.; Qin, J. Human brain organoid-on-a-chip to model prenatal nicotine exposure. Lab Chip 2018, 6, 851-860. [CrossRef]

113. Hardy, J.; Selkoe, D.J. The amyloid hypothesis of Alzheimer's disease: Progress and problems on the road to therapeutics. Science 2002, 5580, 353-356. [CrossRef] [PubMed]

114. Park, J.; Lee, B.K.; Jeong, G.S.; Hyun, J.K.; Lee, C.J.; Lee, S. Three-dimensional brain-on-a-chip with an interstitial level of flow and its application as an In vitro model of Alzheimer's disease. Lab Chip 2015, 1, 141-150. [CrossRef] 
115. Tang, Y.; Qiu, Q.; Zhang, F.; Xie, M.; Huang, W. Quantifying orientational regeneration of injured neurons by natural product concentration gradients in a 3D microfluidic device. Lab Chip 2018, 6, 971-978. [CrossRef] [PubMed]

116. Pabst, R. The anatomical basis for the immune function of the gut. Anat. Embryol. 1987, 2, 135-144. [CrossRef] [PubMed]

117. McConnell, E.L.; Fadda, H.M.; Basit, A.W. Gut instincts: Explorations in intestinal physiology and drug delivery. Int. J. Pharm. 2008, 2, 213-226. [CrossRef]

118. Kim, H.J.; Huh, D.; Hamilton, G.; Ingber, D.E. Human gut-on-a-chip inhabited by microbial flora that experiences intestinal peristalsis-like motions and flow. Lab Chip 2012, 12, 2165. [CrossRef]

119. Kim, H.J.; Ingber, D.E. Gut-on-a-chip microenvironment induces human intestinal cells to undergo villus differentiation. Integr. Biol. Quant. Biosci. Nano Macro 2013, 9, 1130. [CrossRef]

120. Kim, H.J.; Li, H.; Collins, J.J.; Ingber, D.E. Contributions of microbiome and mechanical deformation to intestinal bacterial overgrowth and inflammation in a human gut-on-a-chip. Proc. Natl. Acad. Sci. USA 2016, 1, E7-E15. [CrossRef]

121. Guo, Y.; Li, Z.; Su, W.; Wang, L.; Zhu, Y.; Qin, J. A biomimetic human gut-on-a-chip for modeling drug metabolism in intestine. Artif. Organs 2018, 42, 1196-1205. [CrossRef]

122. Beaurivage, C.; Naumovska, E.; Chang, Y.; Elstak, E.; Nicolas, A.; Wouters, H.; van Moolenbroek, G.; Lanz, H.; Trietsch, S.; Joore, J.; et al. Development of a gut-on-a-chip model for high throughput disease modeling and drug discovery. Int. J. Mol. Sci. 2019, 22, 5661. [CrossRef]

123. De Haan, P.; Ianovska, M.A.; Mathwig, K.; van Lieshout, G.; Triantis, V.; Bouwmeester, H.; Verpoorte, E. Digestion-on-a-chip: A continuous-flow modular microsystem recreating enzymatic digestion in the gastrointestinal tract. Lab Chip 2019, 9, 1599-1609. [CrossRef] [PubMed]

124. Delaunois, L.M. Mechanisms in pulmonary toxicology. Clin. Chest Med. 2004, 1, 1-14. [CrossRef]

125. Zhang, M.; Xu, C.; Jiang, L.; Qin, J. A 3D human lung-on-a-chip model for nanotoxicity testing. Toxicol. Res. 2018, 7, 1048-1060. [CrossRef] [PubMed]

126. Huh, D.; Matthews, B.D.; Mammoto, A.; Montoya-Zavala, M.; Hsin, H.Y.; Ingber, D.E. Reconstituting organ-level lung functions on a chip. Science 2010, 5986, 1662-1668. [CrossRef] [PubMed]

127. Huh, D.; Leslie, D.C.; Matthews, B.D.; Fraser, J.P.; Jurek, S.; Hamilton, G.A.; Thorneloe, K.S.; McAlexander, M.A.; Ingber, D.E. A human disease model of drug toxicity-induced pulmonary edema in a lung-on-a-chip microdevice. Sci. Transl. Med. 2012, 159, 159ra147. [CrossRef]

128. Yang, X.; Li, K.; Zhang, X.; Liu, C.; Guo, B.; Wen, W.; Gao, X. Nanofiber membrane supported lung-on-a-chip microdevice for anti-cancer drug testing. Lab Chip 2018, 18, 486-495. [CrossRef]

129. Felder, M.; Trueeb, B.; Stucki, A.O.; Borcard, S.; Stucki, J.D.; Schnyder, B.; Geiser, T.; Guenat, O.T. Impaired wound healing of alveolar lung epithelial cells in a breathing lung-on-a-chip. Front. Bioeng. Biotechnol. 2019, 7, 3. [CrossRef]

130. Palmiotti, C.A.; Prasad, S.; Naik, P.; Abul, K.M.D.; Sajja, R.K.; Achyuta, A.H.; Cucullo, L. In vitro cerebrovascular modeling in the 21st century: Current and prospective technologies. Pharm. Res. 2014, 12, 3229-3250. [CrossRef]

131. Nicolazzo, J.A.; Charman, S.A.; Charman, W.N. Methods to assess drug permeability across the blood-brain barrier. J. Pharm. Pharm. 2006, 3, 281-293. [CrossRef]

132. Nakagawa, S.; Deli, M.A.; Kawaguchi, H.; Shimizudani, T.; Shimono, T.; Kittel, Á.; Tanaka, K.; Niwa, M. A new blood-Brain barrier model using primary rat brain endothelial cells, pericytes and astrocytes. Neurochem. Int. 2009, 3-4, 253-263. [CrossRef]

133. Booth, R.; Kim, H. Characterization of a microfluidic In vitro model of the blood-brain barrier (muBBB). Lab Chip 2012, 10, 1784-1792. [CrossRef] [PubMed]

134. Vatine, G.; Barrile, R.; Workman, M.; Chen, Z.; Eyk, J.; Svendsen, C. Human iPSC-derived blood-brain barrier chips enable disease modeling and personalized medicine applications. Cell Stem Cell 2019, 24, 995-1005.e6. [CrossRef] [PubMed]

135. Wufuer, M.; Lee, G.; Hur, W.; Jeon, B.; Kim, B.J.; Choi, T.H.; Lee, S. Skin-on-a-chip model simulating inflammation, edema and drug-based treatment. Sci. Rep. 2016, 6, 37471. [CrossRef] [PubMed]

136. Menon, N.V.; Tay, H.M.; Wee, S.N.; Li, K.H.H.; Hou, H.W. Micro-engineered perfusable 3D vasculatures for cardiovascular diseases. Lab Chip 2017, 17, 2960-2968. [CrossRef] [PubMed] 
137. Jin, D.; Ma, X.; Luo, Y.; Fang, S.; Xie, Z.; Li, X.; Qi, D.; Zhang, F.; Kong, J.; Li, J.; et al. Application of a microfluidic-based perivascular tumor model for testing drug sensitivity in head and neck cancers and toxicity in endothelium. RSC Adv. 2016, 35, 29598-29607. [CrossRef]

138. Ronaldson-Bouchard, K.; Vunjak-Novakovic, G. Organs-on-a-chip: A fast track for engineered human tissues in drug development. Cell Stem Cell 2018, 3, 310-324. [CrossRef]

139. Chang, S.; Weber, E.J.; Sidorenko, V.S.; Chapron, A.; Yeung, C.K.; Gao, C.; Mao, Q.; Shen, D.; Wang, J.; Rosenquist, T.A.; et al. Human liver-kidney model elucidates the mechanisms of aristolochic acid nephrotoxicity. JCI Insight 2017, 22. [CrossRef]

140. Theobald, J.; Ghanem, A.; Wallisch, P.; Banaeiyan, A.A.; Andrade-Navarro, M.A.; Taskova, K.; Haltmeier, M.; Kurtz, A.; Becker, H.; Reuter, S.; et al. Liver-kidney-on-chip to study toxicity of drug metabolites. ACS Biomater. Sci. Eng. 2018, 1, 78-89. [CrossRef]

141. Theobald, J.; Abu El Maaty, M.A.; Kusterer, N.; Wetterauer, B.; Wink, M.; Cheng, X.; Wölfl, S. In vitro metabolic activation of vitamin D3 by using a multi-compartment microfluidic liver-kidney organ on chip platform. Sci. Rep. 2019, 9, 4616. [CrossRef]

142. Sung, J.H.; Shuler, M.L. A micro cell culture analog ( $\mu$ CCA) with 3-D hydrogel culture of multiple cell lines to assess metabolism-dependent cytotoxicity of anti-cancer drugs. Lab Chip 2009, 10, 1385. [CrossRef]

143. Oleaga, C.; Bernabini, C.; Smith, A.S.T.; Srinivasan, B.; Jackson, M.; McLamb, W.; Platt, V.; Bridges, R.; Cai, Y.; Santhanam, N.; et al. Multi-organ toxicity demonstration in a functional human In vitro system composed of four organs. Sci. Rep. 2016, 6, 20030. [CrossRef] [PubMed]

144. Li, Z.; Guo, Y.; Yu, Y.; Xu, C.; Xu, H.; Qin, J. Assessment of metabolism-dependent drug efficacy and toxicity on a multilayer organs-on-a-chip. Integr. Biol. 2016, 10, 1022-1029. [CrossRef] [PubMed]

145. McAleer, C.W.; Pointon, A.; Long, C.J.; Brighton, R.L.; Wilkin, B.D.; Bridges, L.R.; Narasimhan Sriram, N.; Fabre, K.; McDougall, R.; Muse, V.P.; et al. On the potential of In vitro organ-chip models to define temporal pharmacokinetic-pharmacodynamic relationships. Sci. Rep. 2019, 9, 9619. [CrossRef] [PubMed]

146. Ishida, S. Organs-on-a-chip: Current applications and consideration points for In vitro ADME-Tox studies. Drug Metab Pharm. 2018, 1, 49-54. [CrossRef]

147. Pamies, D.; Price, A.; Chesne, C.; Coecke, S.; Dinnyes, A.; Eskes, C.; Grillari, R.; Hartung, T.; Leist, M.; Daneshian, M. Advanced good cell culture practice for human primary, stem cell-derived and organoid models as well as microphysiological systems. ALTEX 2018, 35, 353-378. [CrossRef] 